\title{
Historical gaseous and primary aerosol emissions in the United States from 1990 to 2010
}

\author{
J. Xing, J. Pleim, R. Mathur, G. Pouliot, C. Hogrefe, C.-M. Gan, and C. Wei \\ US Environmental Protection Agency, Research Triangle Park, NC 27711, USA \\ Correspondence to: J. Xing (xingjia@tsinghua.org.cn, xing.jia@epa.gov) \\ Received: 22 October 2012 - Published in Atmos. Chem. Phys. Discuss.: 23 November 2012 \\ Revised: 15 March 2013 - Accepted: 1 July 2013 - Published: 6 August 2013
}

\begin{abstract}
An accurate description of emissions is crucial for model simulations to reproduce and interpret observed phenomena over extended time periods. In this study, we used an approach based on activity data to develop a consistent series of spatially resolved emissions in the United States from 1990 to 2010. The state-level anthropogenic emissions of $\mathrm{SO}_{2}, \mathrm{NO}_{\mathrm{x}}, \mathrm{CO}, \mathrm{NMVOC}$ (non-methane volatile organic compounds), $\mathrm{NH}_{3}, \mathrm{PM}_{10}$ and $\mathrm{PM}_{2.5}$ for a total of 49 sectors were estimated based on several long-term databases containing information about activities and emission controls. Activity data for energy-related stationary sources were derived from the State Energy Data System. Corresponding emission factors reflecting implemented emission controls were calculated back from the National Emissions Inventory (NEI) for seven years (i.e., 1990, 1995, 1996, 1999, 2001, 2002 and 2005), and constrained by the AP-42 (US EPA's Compilation of Air Pollutant Emissions Factors) dataset. Activity data for mobile sources including different types of highway vehicles and non-highway equipment were obtained from highway statistics reported by the Federal Highway Administration. The trends in emission factors for highway mobile source were informed by the 2011 National Transportation Statistics. Emissions for all non-energy-related sources were either scaled by the growth ratio of activity indicators or adjusted based on the NEI trends report.

Because of the strengthened control efforts, particularly for the power sector and mobile sources, emissions of all pollutants except $\mathrm{NH}_{3}$ were reduced by half over the last two decades. The emission trends developed in this study are comparable with the NEI trend report and EDGAR (Emissions Database for Global Atmospheric Research) data, but better constrained by trends in activity data. Reductions in $\mathrm{SO}_{2}, \mathrm{NO}_{\mathrm{x}}, \mathrm{CO}$ and EC (speciation of $\mathrm{PM}_{2.5}$ by SMOKE,
\end{abstract}

Sparse Matrix Operator Kernel Emissions) emissions agree well with the observed changes in ambient $\mathrm{SO}_{2}, \mathrm{NO}_{2}, \mathrm{CO}$ and EC concentrations, suggesting that the various controls on emissions implemented over the last two decades are well represented in the emission inventories developed in this study. These inventories were processed by SMOKE and are now ready to be used for regional chemistry transport model simulations over the 1990-2010 period.

\section{Introduction}

Quantification of long-term historic emissions is necessary to assess their impacts on atmospheric chemistry and composition through model simulation and analysis. Recent studies suggest that the observed transition from decadal "dimming" to "brightening" during the 1990s in the continental United States was strongly influenced by the reductions in anthropogenic emissions of aerosol precursors (Streets et al., 2006; Stern, 2006; Wild, 2009). $\mathrm{SO}_{2}$ and $\mathrm{NO}_{\mathrm{x}}$ emissions in particular were required to be reduced by 10 and 2 million tons respectively from their 1980 levels by Title IV of the US Clean Air Act Amendments enacted in 1990. It is believed that such reductions have had considerable effects on anthropogenic aerosol loading and regional radiation budgets over the past two decades. Regional chemistry or climate models are good tools for improving our understanding of the role of aerosols in the decadal changes of solar radiation. However, using such simulations to reproduce and interpret the observed phenomena requires knowledge of changes in the magnitude as well as the spatial and temporal patterns of emissions (Streets et al., 2003). 
Some studies have generated global emissions over extended time periods (Lamarque et al., 2010; Smith et al., 2011). One example is the Emissions Database for Global Atmospheric Research (EDGAR) (European Commission, 2011). Because these inventories typically are resolved at the country or region level, they cannot adequately support regional-scale chemistry or climate model simulations over areas such as the continental United States. The National Emissions Inventory (NEI) data for specific years prepared by the US EPA are a comprehensive and detailed estimate of regional emissions based on detailed information provided by state, local and tribal air agencies for sources in their jurisdictions; it is hereafter referred to as the "NEI data". Because of the continual development of emission-estimation methodology, the inconsistency between different years of NEI data is an obstacle for their use in long-term air quality model simulations. For example, on-road $\mathrm{NO}_{\mathrm{x}}$ emission estimated from MOVES (www.epa.gov/otaq/models/moves/ index.htm) used in 2005 NEI (current newest version 4.2) is much higher than that estimated from its predecessor model MOBILE6, which was used in previous NEI (Lindhjem et al., 2012; McDonald et al., 2012). Besides, when performing long-term analysis of decadal-scale variations and trends, accuracy of trends is as important as accuracy of absolute values. Though national-level sector-based emissions for each year are available from the NEI trends report (US EPA, 2000, http://www.epa.gov/ttnchie1/trends/, referred to as "NEI trends" in this paper), the necessary harmonization of these coarser data with the detailed information available in the periodic NEI data as well as the interpolation for years for which no detailed NEI data are available is challenging (Hogrefe et al., 2009).

In general, emissions from a certain source are calculated by using a specific activity indicator (e.g., fuel consumption) multiplied by source-specific emission factor. Changes of emissions over a period of time can be caused by changes in both activity and emission factors due to emission controls, and such changes are usually fairly well constrained over long periods (Lamarque et al., 2010). For example, the State Energy Data System (http://www.eia.gov/state/seds/) provides a long historic record back to 1960 about the statelevel energy use by broad energy-related sectors (i.e., combustion in electric power, industrial, domestic, transportation), which account for up to $90 \%$ of total emissions of $\mathrm{SO}_{2}$ and $\mathrm{NO}_{\mathrm{x}}$ (the major two species associated with the reduction in anthropogenic aerosol loading) in the United States. Therefore, the approach of scaling the emissions based on the changes in activities and controls would be a good choice to generate a consistent series of emissions particularly for such extended time periods.

To support multi-decadal regional-scale air quality simulations, we developed a consistent series of spatially resolved emission inventories (generated at the county level in SMOKE format, Sparse Matrix Operator Kernel Emissions, http://www.smoke-model.org/data.cfm) in the United
States from 1990 to 2010, by using an approach based on several long-term databases containing information about activity data and emission controls. Our goal is to have a single consistent methodology across the $20 \mathrm{yr}$ period for estimating the primary criteria pollutants for all the major sectors in the NEI. This work is a significant improvement over the NEI data and the NEI trends reports because our estimates capture the annual changes in emissions using a consistent methodology for each sector and we remove artificial step changes found in the NEI and in the trends data due to changes in methods. The state-level anthropogenic emissions of $\mathrm{SO}_{2}, \mathrm{NO}_{\mathrm{x}}, \mathrm{CO}$, NMVOC (non-methane volatile organic compounds), $\mathrm{NH}_{3}, \mathrm{PM}_{10}$ and $\mathrm{PM}_{2.5}$ were estimated. In addition, trends of $\mathrm{SO}_{2}, \mathrm{NO}_{\mathrm{x}}, \mathrm{CO}$ and $\mathrm{EC}$ (speciation of $\mathrm{PM}_{2.5}$ by SMOKE) emissions from 1990 to 2010 were compared with changes in observed ambient $\mathrm{SO}_{2}, \mathrm{NO}_{2}, \mathrm{CO}$ and $\mathrm{EC}$ concentrations.

\section{Method}

\subsection{Development of 1990-2010 emission inventories}

The US EPA National Emissions Inventory (NEI) data are considered as the most comprehensive and detailed estimates of pollution emissions in the United States and have been widely used in modeling studies. Therefore, NEI data serve as the primary reference database in this study. Specifically, this study uses the most recent NEI data as reference and then scales emissions up or down for the other years based on the trends of activity data and emission controls over the entire period. Seven years of detailed NEI data were collected, including those developed for the more recent years of 1999, 2001, 2002 and 2005, which can be directly downloaded from the EPA website (http://www.epa.gov/ttn/chief/; the 2008 NEI was not yet ready for SMOKE processing when our study of inventory development was initiated in 2011) and the three earlier years of 1990, 1995 and 1996, which were developed for previous studies (US EPA, 1993; Adelman and Houyoux, 2001).

The approach we used to develop the long-term emission inventory is given in Fig. 1.

First, to organize each sector better, all point, area and mobile emission sources (obtained from individual files in NEI data) were combined into three major groups (i.e., energy-related stationary sources, mobile sources, nonenergy-related sources) with 49 subsectors based on the SCCs (Source Classification Codes). Details about the combination can be found in Table S1 of the Supplement. All sectors were aggregated at the state level for trend purposes. The 2005 county-level NEI data were used as the reference for most sectors. The 2002 county-level NEI data were used as the reference for some sectors for which the 2005 NEI data were missing (e.g., aircraft) or inconsistent (for example, the on-road $\mathrm{NO}_{\mathrm{x}}$ emission in $2005 \mathrm{NEI}$ is significantly 


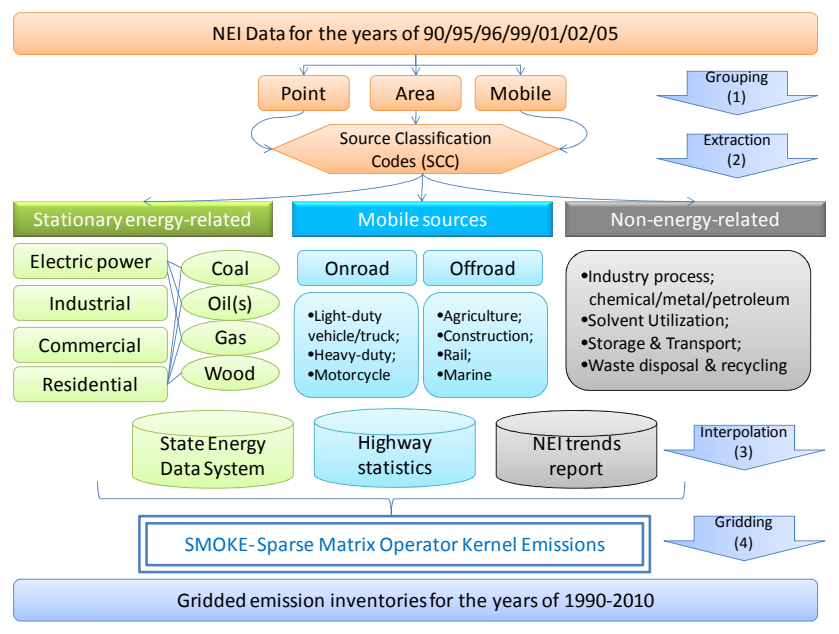

Fig. 1. The framework of the $20 \mathrm{yr}$ emission inventory development.

higher than that reported in NEI trends due to the methodology change from MOBILE to MOVES). However, mobile emission estimates by MOVES were unavailable for the previous $20 \mathrm{yr}$ back to the 1990s. Recent analysis by McDonald et al. (2012) suggests that overall MOBILE6 estimates were closer to EDGAR than MOVES only except for the past few years. For the purpose of this study, we selected the most recent NEI data that were based on MOBILE6 (i.e., 2002 NEI, instead of $2005 \mathrm{NEI}$ ) as the reference for on-road sector.

Additionally, since all sectors have noticeable contributions to total emissions of one or more pollutants (as seen in Table 1), to interpolate properly the emissions, corresponding activity and control information in each sector needs to be collected thoroughly, as shown in Table 2. Details about the approach applied to each sector are described in Sects. 2.1.12.1.3.

Finally, emissions in each sector were scaled by the ratio (relative to the baseline) calculated for each year between 1990 and 2010 at the state level, to generate inventory files for each specific year. SMOKE was then run to generate the spatially and temporally resolved emissions. This is further clarified in the discussion in Sect. 2.2.

\subsubsection{Energy-related stationary sources}

\section{Activity}

Following the structure of the energy data provided by State Energy Data System, emission sources in NEI data were grouped into four major energy-related stationary sources by seven types of fuel categories (total 20 sectors), as seen in Table 1a. Annual time series estimates of state-level energy use by broad energy-related sectors from 1960 to 2010 were directly derived from the State Energy Data System.

\section{Emission factor}

Trends in emission factors for each sector are also needed for the $20 \mathrm{yr}$ period in order to calculate the historical emissions. Originally, the AP-42 emission factors (http://www.epa.gov/ $\mathrm{ttn} / \mathrm{chief} / \mathrm{ap} 42 / \mathrm{index} . \mathrm{html}$ ) were used to calculate the emissions for each source in NEI data. There may be significant differences due to different control levels as well as sorts of combustion technologies (the range of unabated emission factors is given in Table 3). Since it is extremely difficult to obtain such detailed information about the absolute percentage of each control or combustion technology applied in each individual state during $20 \mathrm{yr}$, in this study we just ensured all the averaged emission factors were within a reasonable range informed by the AP-42 dataset. Also we attempted to backcalculate these emission factors from NEI data for $7 \mathrm{yr}$ to quantify the evolution of emission controls.

The emission factor for each sector was calculated based on Eq. (1):

$\mathrm{EF}_{p, s, i, y}=\sum_{n} \operatorname{Emis}_{p, s, i_{n}, y} / \operatorname{Act}_{s, i, y}$,

where $\mathrm{EF}_{p, s, i, y}$ is the calculated emission factor for pollutant $p$ from sector $i$ in state $s$ in the year of $y$; $\operatorname{Emis}_{p, s, i_{n}, y}$ is the emission amount in NEI data for pollutant $p$ from subsector $i_{n}$ of sector $i$ in state $s$ in the year of $y$; Act sti,y $_{\text {is }}$ the energy consumption in sector $i$ in state $s$ in the year of $y$; sub-sector $i_{n}$ means the original sector defined in NEI. For example, the sector "coal combustion in power plant" defined in this study is actually grouped from "sub-sectors" in NEI data (e.g., subbituminous coal combustion in power plant using wet/dry bottom technology).

The emission factors calculated for the $7 \mathrm{yr}$ should satisfy the following rules:

1. all emission factors should be within the range from AP42 , i.e., equal to or smaller than uncontrolled level, and equal to or greater than the maximally controlled level;

2. the emission factor varies with the application of control technologies; thus for any given year it should be no larger than the one for the previous year;

3. if there is no evidence of controls, a consistent emission factor should be applied to all years during the study period.

The rules can be described as Eq. (2):

$\min \left(\mathrm{EF}_{p, s, i, y-1}, \max \mathrm{EF}_{p, i_{n}}\right) \geq \mathrm{EF}_{p, s, i, y} \geq$

$\max \left(\mathrm{EF}_{p, s, i, y+1}, \min \_\mathrm{EF}_{p, i_{n}}\right)$,

where $\max \mathrm{EF}_{p, i_{n}}$ and $\min \mathrm{EF}_{p, i_{n}}$ are respectively uncontrolled and maximum controlled emission factor for pollutant $p$ in sub-sector $i_{n}$.

There are two cases of interpolation of the emission factor for those years when NEI data are unavailable: for uncontrolled sectors, the changes of emissions are only related to 
Table 1. Defined sectors and percentage of their contributions to total anthropogenic emissions (calculated from the 2002 NEI data, unit: $\%$ ).

(a) Energy-related stationary sources

\begin{tabular}{|c|c|c|c|c|c|c|c|c|}
\hline \multicolumn{2}{|c|}{ Sector } & \multicolumn{7}{|c|}{ Pollutant } \\
\hline Group & Type & $\mathrm{NO}_{\mathrm{x}}$ & $\mathrm{SO}_{2}$ & $\mathrm{CO}$ & NMVOC & $\mathrm{PM}_{10}$ & $\mathrm{PM}_{2.5}$ & $\mathrm{NH}_{3}$ \\
\hline \multirow{5}{*}{ Power plants } & Coal & 20.2 & 69.4 & 0.4 & 0.2 & 4.5 & 9.5 & 0.3 \\
\hline & Residual oil & 0.6 & 2.4 & 0.0 & 0.0 & 0.2 & 0.3 & 0.0 \\
\hline & Distillate oil & 0.4 & 0.2 & 0.0 & 0.0 & 0.0 & 0.1 & 0.0 \\
\hline & Natural gas & 1.4 & 0.4 & 0.1 & 0.1 & 0.1 & 0.2 & 0.3 \\
\hline & Total & 22.6 & 72.4 & 0.6 & 0.3 & 4.8 & 10.2 & 0.7 \\
\hline \multirow{5}{*}{ Industrial combustion } & Coal & 1.7 & 7.4 & 0.1 & 0.0 & 1.5 & 1.3 & 0.1 \\
\hline & Residual oil & 0.3 & 1.3 & 0.0 & 0.0 & 0.1 & 0.2 & 0.0 \\
\hline & Distillate oil & 0.6 & 0.9 & 0.0 & 0.0 & 0.1 & 0.2 & 0.1 \\
\hline & Natural gas & 5.2 & 0.2 & 0.4 & 0.4 & 0.1 & 0.2 & 0.2 \\
\hline & Total & 7.7 & 9.9 & 0.6 & 0.5 & 1.8 & 1.9 & 0.4 \\
\hline \multirow{7}{*}{ Commercial combustion } & Coal & 0.2 & 0.9 & 0.0 & 0.0 & 0.3 & 0.2 & 0.0 \\
\hline & Residual fuel oil & 0.1 & 0.6 & 0.0 & 0.0 & 0.0 & 0.0 & 0.0 \\
\hline & Distillate oil & 0.2 & 0.9 & 0.0 & 0.0 & 0.1 & 0.2 & 0.1 \\
\hline & Natural gas & 0.8 & 0.0 & 0.1 & 0.1 & 0.0 & 0.0 & 0.0 \\
\hline & LPG & 0.0 & 0.0 & 0.0 & 0.0 & 0.0 & 0.0 & 0.0 \\
\hline & Kerosene & 0.0 & 0.0 & 0.0 & 0.0 & 0.0 & 0.0 & 0.0 \\
\hline & Total & 1.3 & 2.5 & 0.2 & 0.1 & 0.4 & 0.4 & 0.1 \\
\hline \multirow{7}{*}{ Residential combustion } & Coal & 0.0 & 0.1 & 0.1 & 0.0 & 0.0 & 0.1 & 0.0 \\
\hline & Distillate oil & 0.3 & 0.9 & 0.0 & 0.0 & 0.1 & 0.1 & 0.0 \\
\hline & Natural gas & 1.2 & 0.0 & 0.1 & 0.1 & 0.0 & 0.0 & 0.0 \\
\hline & LPG & 0.2 & 0.0 & 0.0 & 0.0 & 0.0 & 0.0 & 0.0 \\
\hline & Kerosene & 0.0 & 0.1 & 0.0 & 0.0 & 0.0 & 0.0 & 0.0 \\
\hline & Wood & 0.2 & 0.0 & 2.9 & 8.5 & 3.2 & 8.2 & 0.2 \\
\hline & Total & 1.9 & 1.2 & 3.1 & 8.7 & 3.3 & 8.4 & 0.3 \\
\hline \multicolumn{9}{|c|}{ (b) Energy-related mobile sources } \\
\hline \multirow{4}{*}{ Highway } & Light-duty vehicle, gasoline \& diesel & 11.2 & 0.6 & 34.2 & 16.1 & 0.4 & 0.5 & 4.0 \\
\hline & Light-duty truck, gasoline \& diesel & 9.4 & 0.5 & 29.7 & 12.2 & 0.3 & 0.4 & 2.6 \\
\hline & Heavy-duty, gasoline \& diesel & 20.2 & 0.6 & 3.7 & 2.4 & 0.9 & 2.1 & 0.3 \\
\hline & Motorcycle, gasoline & 0.1 & 0.0 & 0.2 & 0.2 & 0.0 & 0.0 & 0.0 \\
\hline & Total & 40.8 & 1.7 & 67.8 & 30.9 & 1.6 & 3.0 & 6.9 \\
\hline \multirow{11}{*}{ Off-highway } & Agriculture, gasoline & 0.0 & 0.0 & 0.1 & 0.0 & 0.0 & 0.0 & 0.0 \\
\hline & Construction, gasoline & 0.0 & 0.0 & 0.5 & 0.2 & 0.0 & 0.0 & 0.0 \\
\hline & Other gasoline & 0.5 & 0.0 & 9.3 & 9.4 & 0.3 & 0.7 & 0.0 \\
\hline & Marine, diesel & 4.0 & 0.6 & 0.1 & 0.1 & 0.2 & 0.6 & 0.0 \\
\hline & Rail, diesel & 5.5 & 0.5 & 0.1 & 0.3 & 0.2 & 0.6 & 0.0 \\
\hline & Other diesel & 5.0 & 0.7 & 0.5 & 0.7 & 0.8 & 1.9 & 0.0 \\
\hline & Marine, residual oil & 1.2 & 1.1 & 0.0 & 0.0 & 0.1 & 0.3 & 0.0 \\
\hline & All natural gas & 0.2 & 0.0 & 0.1 & 0.0 & 0.0 & 0.0 & 0.0 \\
\hline & All LPG & 1.0 & 0.0 & 0.8 & 0.3 & 0.0 & 0.0 & 0.0 \\
\hline & All jet fuel & 0.4 & 0.1 & 0.5 & 0.3 & 0.2 & 0.4 & 0.0 \\
\hline & Total & 17.9 & 3.0 & 12.0 & 11.5 & 1.9 & 4.5 & 0.1 \\
\hline
\end{tabular}

changes in activity. Therefore, the emission factor is kept the same over the period.

For controlled sectors, the emission factor between two available years was constrained by national-level NEI trends information, described as Eq. (3).

$$
\left\{\begin{array}{l}
\mathrm{EF}_{p, s, i, y}=\mathrm{EF}_{p, s, i, p y}-\frac{\mathrm{Act}_{s, i, p y}}{\mathrm{Act}_{s, i, y}} \times\left(\mathrm{EF}_{p, s, i, p y}-\mathrm{EF}_{p, s, i, n y}\right) \\
\times\left(\frac{\mathrm{ef}_{p, i, p y}-\mathrm{ef}_{p, i, y}}{\mathrm{ef}_{p, i, p y}-\mathrm{ef}_{p, i, n y}}\right)(p y<y<n y \leq 2005) \\
\mathrm{EF}_{p, s, i, y}=\mathrm{EF}_{p, s, i, p y} \times \frac{\mathrm{ef}_{p, i, y}}{\mathrm{ef}_{p, i, p y}}(y>p y \geq 2005)
\end{array}\right.
$$


Table 1. Continued.

\begin{tabular}{|c|c|c|c|c|c|c|c|c|}
\hline (c) Non-energy-rela & Sector & & & & Pollutan & & & \\
\hline Group & Type & $\mathrm{NO}_{\mathrm{x}}$ & $\mathrm{SO}_{2}$ & $\mathrm{CO}$ & NMVOC & $\mathrm{PM}_{10}$ & $\mathrm{PM}_{2.5}$ & $\mathrm{NH}_{3}$ \\
\hline \multirow{5}{*}{ Industry processes } & Chemical manufacturing & 0.5 & 1.8 & 0.4 & 1.5 & 0.3 & 0.6 & 0.6 \\
\hline & Metals processing & 0.4 & 1.6 & 1.0 & 0.3 & 0.7 & 1.2 & 0.1 \\
\hline & Petroleum \& related industries & 2.2 & 2.6 & 0.4 & 3.6 & 0.2 & 0.4 & 0.1 \\
\hline & Other industry processes & 2.5 & 2.6 & 0.5 & 2.6 & 3.2 & 5.1 & 4.6 \\
\hline & Total & 5.6 & 8.7 & 2.3 & 8.1 & 4.4 & 7.4 & 5.3 \\
\hline \multirow{12}{*}{ Other } & Solvent utilization & 0.0 & 0.0 & 0.0 & 24.7 & 0.1 & 0.1 & 0.0 \\
\hline & Storage \& transport & 0.0 & 0.0 & 0.0 & 8.4 & 0.0 & 0.0 & 0.0 \\
\hline & Waste disposal \& recycling & 0.5 & 0.2 & 1.5 & 2.2 & 2.2 & 5.4 & 0.7 \\
\hline & Construction processes & 0.0 & 0.0 & 0.0 & 0.0 & 6.9 & 4.0 & 0.0 \\
\hline & Paved/unpaved road & 0.0 & 0.0 & 0.0 & 0.0 & 40.1 & 19.5 & 0.0 \\
\hline & Mining \& quarrying & 0.0 & 0.0 & 0.0 & 0.0 & 4.7 & 2.4 & 0.0 \\
\hline & Agriculture crop & 0.3 & 0.1 & 1.9 & 1.0 & 19.3 & 15.4 & 30.0 \\
\hline & Agriculture livestock & 0.0 & 0.0 & 0.0 & 0.2 & 0.8 & 0.4 & 54.4 \\
\hline & Forest wildfires & 0.9 & 0.3 & 7.7 & 2.2 & 6.2 & 13.8 & 1.0 \\
\hline & Prescribed burning for forest management & 0.2 & 0.1 & 1.6 & 0.5 & 1.3 & 3.0 & 0.2 \\
\hline & Miscellaneous & 0.1 & 0.0 & 0.8 & 0.8 & 0.1 & 0.3 & 0.0 \\
\hline & Total & 2.1 & 0.8 & 13.5 & 40.1 & 81.8 & 64.3 & 86.2 \\
\hline
\end{tabular}

where $\mathrm{ef}_{p, i, y}$ is the national-averaged emission factor for pollutant $p$ from sector $i$ in the year of $y$ calculated from NEI trends; $p y$ and $n y$ are the two available years around the year of $y$.

\subsubsection{Mobile sources}

\section{Activity}

Activity data for mobile sources by types of highway vehicles and non-highway equipment were obtained from the highway statistics reported by Federal Highway Administration (http://www.fhwa.dot.gov/policyinformation). On-road sources from NEI data were grouped into four types of onroad vehicles: light-duty vehicle, light-duty truck, heavyduty vehicle/truck and motorcycles. Vehicle miles traveled (VMT) rather than energy consumption was used as the activity indicator for each type of vehicle, in order to match with the estimated emission factors and emissions certification standards in which the given unit is grams per mile (obtained from 2011 National Transportation Statistics).

The VMT was calculated by using vehicle population multiplied by the average distance traveled per vehicle (DPV), as shown in Eq. (4), where $\mathrm{VMT}_{s, i, y}$ is the calculated annual VMT for type $i$ of vehicle in state $s$ in the year of $y$; Population $_{s, i_{n}, y}$ is the vehicle populations for sub-type $i_{n}$ of type $i$ in state $s$ in the year of $y$; and $\mathrm{DPV}_{i_{n}, y}$ is the DPV for sub-type $i_{n}$ of vehicle type $i$ in year $y$.

$\mathrm{VMT}_{s, i, y}=\sum_{n}\left(\right.$ Population $\left._{s, i_{n}, y} \times \mathrm{DPV}_{i_{n}, y}\right)$
The state-level population of each type of vehicle is provided by the highway statistics. The evolution of DPV over the past two decades was obtained from the 2011 National Transportation Statistics.

The fuel usage by vehicle type was also estimated by Eq. (5) to examine the consistency in aspect of energy consumption provided by both highway statistics and State Energy Data System.

$\mathrm{ENE}_{s, i, y}=\sum_{n}\left(\right.$ Population $\left._{s, i_{n}, y} \times \mathrm{DPV}_{i_{n}, y} \times \mathrm{FE}_{i_{n}, y}\right)$,

where $\mathrm{ENE}_{s, i, y}$ is the estimated annual fuel usage for type $i$ of vehicle in state $s$ in year $y$ and $\mathrm{FE}_{i_{n}, y}$ is the fuel efficiency for sub-type $i_{n}$ of vehicle type $i$ in year $y$, representing gallons of gas/diesel per average miles traveled.

The fuel efficiency for each type of vehicle in 1990-2010 was obtained from 2011 National Transportation Statistics. Since the fuel efficiency presents an increasing trend from 1990 to 2010 due to the improvement of technology, the increase in fuel usage is a little smaller than that in VMT. Trends in annual fuel consumption for each mobile sector from 1990 to 2010 are presented in Fig. S1. The mobile gasoline and diesel consumption estimated in this study agrees well with the one in State Energy Data System and Dallmann and Harley (2010).

To derive activity data for off-road sources, the sources were grouped by fuel type (i.e., residual oil, natural gas, LPG (liquefied petroleum gas) and jet fuel), and diesel and gasoline off-road equipment were further divided into $6 \mathrm{sec}$ tors based on more detailed information provided by highway statistics, as seen in Table 1b. Diesel fuel consumption 
Table 2. Summary of data sources used for scaling emissions.

\begin{tabular}{|c|c|c|c|c|}
\hline \multirow{2}{*}{\multicolumn{3}{|c|}{ Sector }} & \multicolumn{2}{|c|}{ Emission constraints } \\
\hline & & & Activity indicator & Control info \\
\hline $\begin{array}{l}\text { Energy- } \\
\text { related } \\
\text { stationary }\end{array}$ & $\begin{array}{l}\text { Power plants } \\
\text { Industrial } \\
\text { Commercial } \\
\text { Residential }\end{array}$ & $\begin{array}{l}\text { Coal, residual oil, } \\
\text { Distillate oil, } \\
\text { Natural gas, LPG, } \\
\text { Kerosene, wood }\end{array}$ & $\begin{array}{l}\text { State-based energy } \\
\text { combustion by fuel types } 1\end{array}$ & $\begin{array}{l}\text { Unit-level } \\
\text { database }^{2} \\
\mathrm{NEI}^{3}\end{array}$ \\
\hline \multirow[t]{2}{*}{$\begin{array}{l}\text { Energy- } \\
\text { related } \\
\text { mobile }\end{array}$} & On-road & $\begin{array}{l}\text { Light-duty vehicle } \\
\text { Light-duty truck } \\
\text { Heavy-duty } \\
\text { Motorcycle }\end{array}$ & $\begin{array}{l}\text { State-based vehicle miles } \\
\text { traveled by vehicle types }\end{array}$ & $\begin{array}{l}\text { Evolution of } \\
\text { emission } \\
\text { factors by } \\
\text { vehicle types } 5\end{array}$ \\
\hline & Off-road & $\begin{array}{l}\text { Agriculture, gasoline } \\
\text { Construction, gasoline } \\
\text { Other gasoline } \\
\text { Marine, diesel } \\
\text { Rail, diesel } \\
\text { Other diesel }\end{array}$ & $\begin{array}{l}\text { State-based gasoline } \\
\text { consumption by } \\
\text { equipment types }{ }^{4} \\
\text { National diesel consumption } \\
\text { by equipment types } 4 \\
\text { Total distillate fuel oil } \\
\text { and kerosene sales } \\
\text { by end use } \\
\text { State-based energy } \\
\text { consumption by } \\
\text { fuel types }\end{array}$ & NEI \\
\hline
\end{tabular}

\begin{tabular}{|c|c|c|c|c|}
\hline \multicolumn{3}{|c|}{ Sector } & \multicolumn{2}{|c|}{ Emission constraints } \\
\hline & & & Activity indicator & Control info \\
\hline \multirow{14}{*}{$\begin{array}{l}\text { Non- } \\
\text { energy- } \\
\text { related }\end{array}$} & Industry & Chemical manufacturing & NEI & \\
\hline & process & Metals processing & NEI & \\
\hline & & Petroleum industries & NEI & \\
\hline & & Other processes & NEI & \\
\hline & Other & Solvent utilization & $\begin{array}{l}\text { Quantity of shipments of } \\
\text { Paint and allied products }{ }^{7}\end{array}$ & NEI \\
\hline & & $\begin{array}{l}\text { Construction } \\
\text { processes }\end{array}$ & $\begin{array}{l}\text { USD spent } \\
\text { on construction }^{8}\end{array}$ & NEI \\
\hline & & $\begin{array}{l}\text { Paved/unpaved } \\
\text { road }\end{array}$ & $\begin{array}{l}\text { State-based vehicle } \\
\text { miles traveled }^{4}\end{array}$ & NEI \\
\hline & & Storage and transport & NEI & \\
\hline & & $\begin{array}{l}\text { Waste disposal } \\
\text { and recycling }\end{array}$ & \multicolumn{2}{|c|}{ Keep the same over the period } \\
\hline & & Mining and quarrying & \multirow{2}{*}{\multicolumn{2}{|c|}{$\begin{array}{l}\text { crude ore and coal handled on surface mine } \\
\text { number of acres harvested for each crop }\end{array}$}} \\
\hline & & $\begin{array}{l}\text { Agriculture tilling and } \\
\text { fertilizer application }\end{array}$ & & \\
\hline & & Livestock & \multicolumn{2}{|c|}{ Livestock operations 9} \\
\hline & & Forest fires & \multicolumn{2}{|c|}{ Acres burned $^{12}$} \\
\hline & & Miscellaneous & \multicolumn{2}{|c|}{ Keep the same over the period } \\
\hline
\end{tabular}

Data were obtained from the following: ${ }^{1}$ State Energy Data System, http://www.eia.gov/state/seds/. ${ }^{2}$ Air Markets Program Data, http://camddataandmaps.epa.gov/gdm. ${ }^{3} \mathrm{NEI}$ trends report, http://www.epa.gov/ttnchie1/trends. ${ }^{4}$ Highway statistics, http://www.fhwa.dot.gov/policyinformation/index.cfm. ${ }^{5} 2011$ National Transportation Statistics, http://www.bts.gov/. ${ }^{6}$ US Energy Information Administration, http://www.eia.gov/petroleum/fueloilkerosene/. ${ }^{7}$ American Coating Association, http://www.paint.org/about- our-industry/item/310.html. ${ }^{8}$ United States Census Bureau, http://www.census.gov/construction/c30/totpage.html. ${ }^{9}$ Minerals Yearbook, http://minerals.usgs.gov/minerals/pubs/commodity/m\&q/index.html\#myb. ${ }^{10}$ Annual Coal Report, http://www.eia.gov/cneaf/coal/cia/cia_sum.html. ${ }^{11}$ Department of Agriculture National Agricultural Statistics Service, http://www.nass.usda.gov/. ${ }^{12}$ National Interagency Fire Center, http://www.nifc.gov/fireInfo/fireInfo_statistics.html. 
for other off-road equipment (except railroad and marine) was calculated based on the method provided by Kean et al. (2000), since such diesel fuel used is excluded from taxable fuel sales reported by highway statistics. Energy consumption in each sector is regarded as the activity indicator, which was obtained from State Energy Data System and highway statistics.

\section{Emission factor}

Following the approach described above for stationary sectors, emission factors for each mobile sector by state were back-calculated from NEI data. The difference is that we only chose the calculated emission factor from the 2002 NEI (the reason that we did not use 2005 NEI is given in Sect. 2.1) as a reference. The evolution of emission factors from 1990 to 2010 was informed by 2011 National Transportation Statistics, which gives the estimated national average emission rates by vehicle type from the results of MOBILE6, the same model as the one used in 2002 NEI. We scaled the emission factors for the whole period by the ratios obtained from the 2011 National Transportation Statistics (the diesel fraction informed by MOBILE6 default data was used to average the trends of emission factors of gasoline and diesel for the same vehicle size), as Eq. (6), where $\mathrm{EF}_{p, s, i, y}$ is the calculated emission factor for pollutant $p$ from vehicle type $i$ in state $s$ in year $y$; ef $_{p, i, y}$ is the emission factor obtained from National Transportation Statistics, and $p y$ is the baseline year as 2002 .

$\mathrm{EF}_{p, s, j, y}=\mathrm{EF}_{p, s, j, p y} \times \frac{\mathrm{ef}_{p, i, y}}{\mathrm{ef}_{p, i, p y}}$

For non-road sources, unfortunately AP-42 does not provide emission factors that we can directly use for comparison, since it is all embedded in the non-road model. In order to ensure that those back-calculated emission factors are within the normal range, the calculated emission factor for each sector was validated through comparison with the corresponding factor in GAINS (Greenhouse Gas and Air Pollution Interactions and Synergies model, http://gains.iiasa.ac.at/index.php/ gains-europe, developed by IIASA, International Institute for Applied Systems Analysis), which provides a full range of emission factors from unabated to maximally controlled for each non-road sector. The evolution of emission factors for non-road diesel and gasoline equipment was informed by NEI trends and Dallmann and Harley (2010). Dallmann and Harley (2010) suggested that $\mathrm{NO}_{\mathrm{x}}$ and PM emission factors for off-road diesel-powered engines decreased significantly between 1996 and 2006. According to their results and NEI trends, we assumed the average $\mathrm{NO}_{\mathrm{x}}$ and $\mathrm{PM}$ emission factors from off-road sources decreased by 25 and $18 \%$ over the past two decades. Due to the introduction of oil with lower sulfur content, the average emission factor of $\mathrm{SO}_{2}$ in transportation decreased by $40 \%$.

\subsubsection{Non-energy-related sources}

Using the categories defined in NEI trends as well as the importance of each emission source, all non-energy-related sources were combined into two groups with 16 sectors, as seen in Table 1c.

The first group is industrial processes, which contributes less than $10 \%$ of total emissions for all pollutants. Considering the difficulties in collecting $20 \mathrm{yr}$ activities for those numerous industrial processes, we simply estimated their historic emissions by scaling the 2005 NEI data with nationallevel NEI trends, using linear fit method shown in Eq. (7).

$\operatorname{Emis}_{p, s, i, y}=\operatorname{Emis}_{p, s, i, r y} \times \frac{\operatorname{emis}_{p, i, y}}{\operatorname{emis}_{p, i, r y}}$,

where emis en $, i, y$ and emis ${ }_{p, i, r y}$ are the national emissions from NEI trends for year $y$ and $r y$ (reference year).

The rest of non-energy-related sources were grouped into 12 sectors, each of which primarily contributes to one or two specific pollutants. There are two cases when interpolating their emissions to the other years from the reference year: (i) for uncontrolled sectors, the $20 \mathrm{yr}$ emissions were simply scaled by following the trend of activities, as in Eq. (8):

$\operatorname{Emis}_{p, s, i, y}=\operatorname{Emis}_{p, s, i, r y} \times \frac{\operatorname{Act}_{p, s, i, y}}{\operatorname{Act}_{p, s, i, r y}}$,

where $\operatorname{Act}_{p, s, i, y}$ and $\operatorname{Act}_{p, s, i, r y}$ are the activities in sector $i$ in state $s$ for year $y$ and $r y$ (reference year).

For controlled sectors (ii), an additional constraint was introduced by using national-level NEI trends, described as Eq. (9):

$\operatorname{Emis}_{p, s, i, y}=\operatorname{Emis}_{p, s, i, r y} \times \frac{\operatorname{Act}_{p, s, i, y}}{\operatorname{Act}_{p, s, i, r y}} \times \frac{\left(\mathrm{emis}_{p, i, y} / a c t_{i, y}\right)}{\left(\operatorname{emis}_{p, i, r y} / a c t_{i, r y}\right)}$,

where $\mathrm{Act}_{i, y}$ and $\mathrm{Act}_{i, r y}$ are the national activities in sector $i$ for year $y$ and $r y$ (reference year).

The sources of the activity data for the different sectors are described below.

\section{VOC-related sources}

Solvent utilization accounts for up to $25 \%$ of total volatile organic compound (VOC) emissions and half of nonenergy-related VOC emissions. Activity data were obtained from the national quantity of shipments of paint and allied products from 1990 to 2010 (http://www.paint. org/about-our-industry/item/310.html). Emissions were constrained by NEI trends.

Storage and transport account for $8 \%$ of total VOC emissions. As with industrial processes, we estimated historic emissions by scaling the 2005 NEI data with national-level NEI trend using Eq. (6). 
Table 3. Summary of $\mathrm{NO}_{\mathrm{x}}$ and $\mathrm{SO}_{2}$ emission factors in energy-related stationary and non-road sectors (unit: $0.01 \mathrm{lb} / \mathrm{MMBtu}$ ).

\begin{tabular}{|c|c|c|c|c|c|c|c|c|c|}
\hline \multirow{3}{*}{ Sector } & \multirow{3}{*}{ Fuel } & \multicolumn{4}{|c|}{$\mathrm{NO}_{\mathrm{x}}$ Emission factor } & \multicolumn{4}{|c|}{$\mathrm{SO}_{2}$ Emission factor } \\
\hline & & \multicolumn{3}{|c|}{ This study } & \multirow{2}{*}{ Unabated $^{1}$} & \multicolumn{3}{|c|}{ This study } & \multirow{2}{*}{ Unabated } \\
\hline & & 1990 & 2010 & $\Delta^{2}$ & & 1990 & 2010 & $\Delta$ & \\
\hline \multirow{4}{*}{ Power plants } & Coal & 79 & 23 & $-71 \%$ & $7-127$ & 211 & 59 & $-72 \%$ & $3-512^{3}$ \\
\hline & Residual oil & 31 & 23 & $-28 \%$ & $21-31$ & 105 & 77 & $-27 \%$ & $105^{4}$ \\
\hline & Distillate oil & 34 & 34 & - & $17-34$ & 73 & 25 & $-66 \%$ & $101-107$ \\
\hline & Natural gas & 28 & 7.6 & $-72 \%$ & $10-28$ & 0.06 & 0.06 & - & 0.06 \\
\hline \multirow{4}{*}{ Industrial combustion } & Coal & 57 & 36 & $-37 \%$ & $7-127$ & 192 & 102 & $-47 \%$ & $3-512$ \\
\hline & Residual oil & 37 & 37 & - & $27-37$ & 104 & 78 & $-25 \%$ & 105 \\
\hline & Distillate oil & 24 & 24 & - & $14-34$ & 46 & 23 & $-50 \%$ & $101-107$ \\
\hline & Natural gas & 27 & 20 & $-23 \%$ & $10-28$ & 0.06 & 0.06 & - & 0.06 \\
\hline \multirow{6}{*}{ Commercial combustion } & Coal & 66 & 66 & - & $7-127$ & 472 & 296 & $-37 \%$ & $3-512$ \\
\hline & Residual fuel oil & 37 & 37 & - & $31-37$ & 92 & 67 & $-27 \%$ & 105 \\
\hline & Distillate oil & 17 & 17 & - & $14-17$ & 89 & 42 & $-52 \%$ & $101-107$ \\
\hline & Natural gas & 12 & 12 & - & $10-28$ & 0.06 & 0.06 & - & 0.06 \\
\hline & LPG & 14 & 14 & - & $13-16$ & 0.02 & 0.02 & - & 0.02 \\
\hline & Kerosene & 17 & 17 & - & $7-17$ & 68 & 68 & - & $101-107$ \\
\hline \multirow{6}{*}{ Residential combustion } & Coal & 66 & 66 & - & $7-127$ & 498 & 225 & $-55 \%$ & $3-512$ \\
\hline & Residual oil & 13 & 13 & - & 13 & 75 & 34 & $-55 \%$ & 101 \\
\hline & Natural gas & 12 & 12 & - & $10-28$ & 0.06 & 0.06 & - & 0.06 \\
\hline & LPG & 16 & 16 & - & $13-16$ & 0.02 & 0.02 & - & 0.02 \\
\hline & Kerosene & 13 & 13 & - & 13 & 57 & 57 & - & 101 \\
\hline & Wood & 15 & 15 & - & 15 & 2.3 & 2.3 & - & 2.3 \\
\hline \multirow{6}{*}{ Off-road transport } & Gasoline & 46 & 46 & - & $7-200$ & 1.4 & 0.8 & $-42 \%$ & $0.1-1.0$ \\
\hline & Diesel & 300 & 224 & $-25 \%$ & $209-326$ & 55 & 35 & $-35 \%$ & $0.1-55$ \\
\hline & Residual fuel oil & 77 & 77 & - & 326 & 55 & 55 & - & $0.1-55$ \\
\hline & Natural gas & 6.8 & 6.8 & - & $7-200$ & 0.01 & 0.01 & - & 0.00 \\
\hline & LPG & 6.8 & 6.8 & - & $7-196$ & 0.01 & 0.01 & - & 0.00 \\
\hline & Jet Fuel & 8.0 & 8.0 & - & 9.0 & 0.7 & 0.7 & - & 0.7 \\
\hline
\end{tabular}

\footnotetext{
1 The unabated emission factors for stationary sectors are from the AP-42 dataset. The unit has been changed to lb/MMBtu, divided by the heating value. The range represents all the situations under different types of firing configuration. For off-road transport, the values refer to GAINS datasets. ${ }^{2}$ The relative change from the year 1990, i.e., $\left(\mathrm{EF}_{2010}-\mathrm{EF}_{1990}\right) / \mathrm{EF}_{1990} \times 100 \%{ }^{3}$ The value was calculated based on $3.4 \%$ sulfur content in coal, applied to all other sectors. ${ }^{4}$ The value was calculated based on $1 \%$ sulfur content in oil, applied to all other sectors.
}

\section{$\mathrm{NH}_{3}$-related sources}

The activity data used for fertilizer application (i.e., agriculture crop shown in Table 1c) were the sum of the number of acres harvested multiplied by the nitrogen fertilizer application rate for each crop, obtained from Department of Agriculture National Agricultural Statistics Service (http: //www.nass.usda.gov/).

The trend of $\mathrm{NH}_{3}$ emission from livestock was estimated by summing the number of head obtained from the 1990-2010 Survey of Agriculture (http://www.nass.usda. gov/) weighted by the $\mathrm{NH}_{3}$ emission factor for each animal. These data included state-level estimates of number of head for the following livestock: cattle, hogs, poultry and sheep.

\section{PM-related sources}

Construction dust accounts for 7 and $4 \%$ of total $\mathrm{PM}_{10}$ and $\mathrm{PM}_{2.5}$ emissions in 2002. Previous studies suggested that the activity could be represented by the acres of land under construction estimated from the USD spent on construction (US EPA, 1998). Net values of construction work in residential, highway, street, and bridge construction, and other non-residential construction in year 2002 and 2007 by states as well as national trends from 1992 to 2010 were used for scaling. In order to remove the effects of inflation, the earnings data were converted to 1990 constant USD using the implicit price deflator for personal consumption expenditures (http://www.bea.gov/national/nipaweb/DownSS2.asp).

Mining and quarrying dust accounts for 5 and $2 \%$ of total $\mathrm{PM}_{10}$ and $\mathrm{PM}_{2.5}$ emissions in 2002. According to the methodology described in NEI trends, the historic emissions 
in this sector are estimated by the sum of the amount of crude ore and coal handled at surface mines weighted by their corresponding $\mathrm{PM}_{10}$ emission factors. The amount of regional crude ore by state was obtained from the US Geological Survey (http://minerals.usgs.gov/minerals/pubs/commodity/ $\mathrm{m} \backslash \& \mathrm{q} /$ index.html\#myb). The coal productions at surface mines were obtained from annual coal industry report (http: //www.eia.gov/cneaf/coal/cia/cia_sum.html).

Agriculture tilling accounts for 19 and $15 \%$ of total $\mathrm{PM}_{10}$ and $\mathrm{PM}_{2.5}$ emissions in 2002. According to the methodology in NEI trends, the activity for agriculture tilling is the number of acres of each crop in production multiplied by its corresponding number of passes and tillings. The acres planted for each crops for years 1990-2010 by state were obtained from the National Agricultural Statistics Service (http://www.nass.usda.gov/). Parameters of its corresponding number of passes and tillings for each type of crops were informed by NEI trends report.

Forest fires account for 7 and $17 \%$ of total $\mathrm{PM}_{10}$ and $\mathrm{PM}_{2.5}$ emissions, including wildland and prescribed fires. Their activities were obtained from acres burned state and national data by National Interagency Fire Center (http://www. nifc.gov/fireInfo/fireInfo_statistics.html).

Paved and unpaved road emissions are the most important PM sources, accounting for 40 and $20 \%$ of total $\mathrm{PM}_{10}$ and $\mathrm{PM}_{2.5}$ emissions. Its emission trend was estimated by statebased vehicle miles traveled with constraint of NEI trends.

\section{Others}

Information about the evolution of emissions from waste disposal and recycling and other miscellaneous sources was not available. We simply set their emissions to be the same over the period.

\subsection{Processing for regional-scale model simulations and comparison with measurements}

To support regional-scale air model simulations, the $20 \mathrm{yr}$ county-level emission inventories developed as described in Sect. 2.1 were processed by SMOKE to generate the spatially and temporally resolved emissions over a $12 \mathrm{~km} \times 12 \mathrm{~km}$ CONUS (continental United States) modeling domain.

1. The most recent NEI inventory files (in IDA or ORL format) were split into 49 sectors by SCCs. Emissions in each sector were scaled by the ratio (to baseline) calculated for year 1990 to 2010 at the state level, to generate inventory files for each year. Spatial and temporal reference files were obtained from the most recent NEI dataset and applied for all the years.

2. Spatial allocation: point sources are assigned to grid cells using the geographic coordinates. For area and mobile sources, a cross-reference file was used to match the gridding surrogates to the source level emissions.
3. Temporal allocation: hourly continuous emissions monitoring (CEM, http://ampd.epa.gov/ampd/) data from 1995 to 2010 were used for point source emissions. Similar temporal cross-reference and profile files were used for other sources.

Some studies (Lu et al., 2010; Wang et al., 2012) indicate that there is a highly linear relationship between the ambient concentrations of short-lived species (like $\mathrm{SO}_{2}$ and $\mathrm{NO}_{2}$ ) and their local emissions because their regional transport impacts are negligible. In this study, we collected long-term trends of observed $\mathrm{SO}_{2}, \mathrm{NO}_{2}, \mathrm{CO}$ and $\mathrm{EC}$ concentrations to compare with the emission trends developed as described in Sect. 2.1.

The 1990-2010 annual mean $\mathrm{SO}_{2}$ concentrations over the United States were downloaded from the CASTNET dataset (Clean Air Status and Trends Network, http://epa. gov/castnet/javaweb/index.html). Data for $\mathrm{SO}_{2}, \mathrm{NO}_{2}, \mathrm{CO}$ concentrations monitored by Air Quality System (AQS) were downloaded from the EPA website (Air Quality Trends by City, 1990-2010, http://www.epa.gov/airtrends/factbook. $\mathrm{html})$. Data for EC were obtained from IMPROVE network (Interagency Monitoring of Protected Visual Environments, http://vista.cira.colostate.edu/IMPROVE/). Trends of observed $\mathrm{SO}_{2}, \mathrm{NO}_{2}, \mathrm{CO}$ and $\mathrm{EC}$ concentrations respectively monitored at 39 CASTNET/96 AQS, 69 AQS, 89 AQS and 30 IMPROVE sites, having $20 \mathrm{yr}$ of completeness, were used to compare with the trends of $\mathrm{SO}_{2}, \mathrm{NO}_{\mathrm{x}}, \mathrm{CO}$ and $\mathrm{EC}$ emissions at the same spatial location. For the purpose of this analysis, emissions from the 81 grids located nearest to each monitor were summed; thus, the emissions in a roughly $100 \mathrm{~km} \times 100 \mathrm{~km}$ area around each monitor are assumed to impact the concentrations measured at the monitor.

\section{Results}

\subsection{Emission inventory from 1990 to 2010}

Based on the method we discussed in Sect. 2.1, the $20 \mathrm{yr}$ emission inventories were developed. The following sections give the discussion about the results by sector.

\subsubsection{Power plants}

Coal-fired power plants, which in 2002 accounted for 69 and $20 \%$ of total $\mathrm{SO}_{2}$ and $\mathrm{NO}_{\mathrm{x}}$ emissions respectively, were the major control targets in the Acid Rain Program that started in 1990 (http://www.epa.gov/airmarkets/progsregs/arp/). Later, advanced $\mathrm{SO}_{2}$ control technologies such as flue gas desulfurization (FGD) were widely applied. The FGD application ratio in coal-fired power plants increased from $21 \%$ in 1990 to $56 \%$ in 2010, as seen in Fig. S2. Because of the marketbased initiative program that reduced $\mathrm{SO}_{2}$ emissions in a cost-efficient manner by using emission trading, most FGD controls were applied to the units that consumed higher sulfur content coal to obtain the maximum cost benefit. From 
(a) Coal-fired

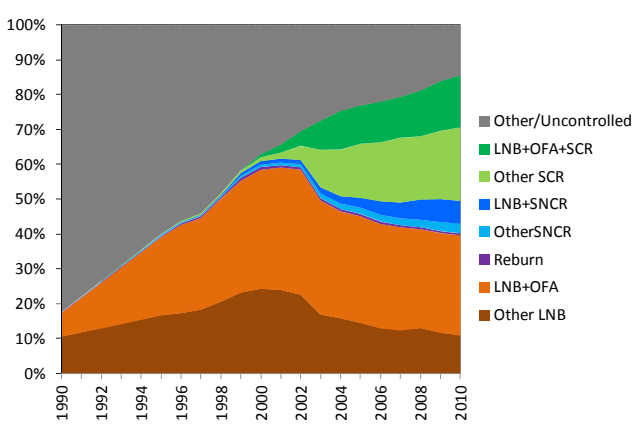

(b) Oil-fired

(c) Gas-fired

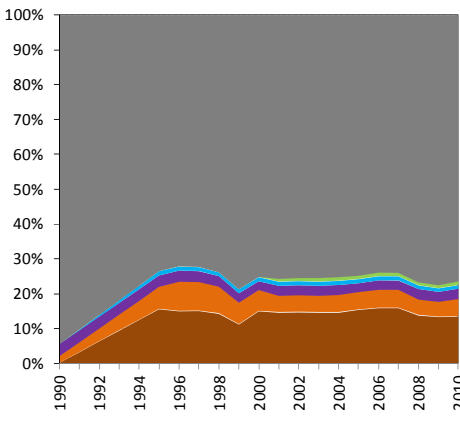

- Other/Uncontrolle - LNB+OFA+SCR Other SCR - $\mathrm{LNB}+\mathrm{SNCR}$ OtherSNCR Reburn Reburn Other LNB

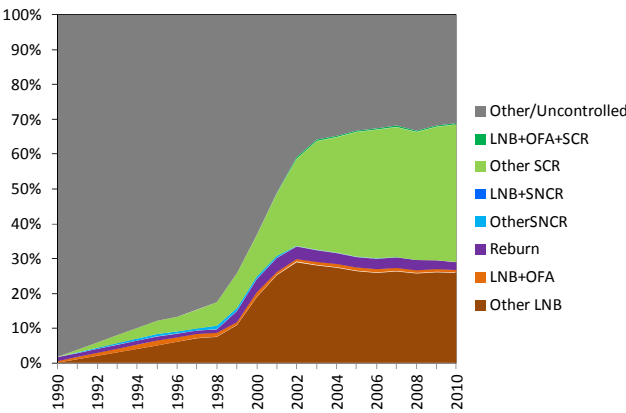

Fig. 2. Application of $\mathrm{NO}_{\mathrm{x}}$ control technologies in power plants from 1990 to 2010 by primary fuel type (weighted by unit capacity, LNB - low $\mathrm{NO}_{\mathrm{x}}$ burners; OFA - overfire air; SNCR - selective non-catalytic reduction; SCR - selective catalytic reduction; based on the Clean Air Markets data, http://ampd.epa.gov/ampd/).

our estimates, the average $\mathrm{SO}_{2}$ emission factor in coal-fired power plants decreased by more than $70 \%$ during the last two decades, as seen in Table 3. The average $\mathrm{SO}_{2}$ emission factor in oil-fired units also decreased by around 30-60\%, partly because the sulfur content of oil decreased due to the "spillover effect" from the impact of lowering the sulfur content on highway diesel (Bookhart and Zien, 2003).

Control efforts also reduced $\mathrm{NO}_{\mathrm{x}}$ emissions in power plants during the Acid Rain Program as well as from the $\mathrm{NO}_{\mathrm{x}}$ Budget Trading Program (NBP) that started in 2003 (http://www.epa.gov/airmarkt/progsregs/nox/sip.html). Figure 2 gives the application ratios of $\mathrm{NO}_{\mathrm{x}}$ control technologies (weighted by unit capacity) in power plants from 1990 to 2010, which increased dramatically for all types of fuel combustion in power plants. More advanced postcombustion control technologies like selective catalytic re- duction (SCR), selective non-catalytic reduction (SNCR) as well as their combinations with traditional combustion modification like overfire air (OFA), and low $\mathrm{NO}_{\mathrm{x}}$ burners (LNB) have been widely applied in coal-fired and natural gas-fired units since Phase II Stage (starting 1 January 2000) of the Acid Rain Program. In 2010, $\mathrm{NO}_{\mathrm{x}}$ control application ratios reached 86 and $70 \%$ of total coal-fired and natural gas-fired units, respectively. Almost half of the control units applied SCR. LNB is the most prevalent control technology used in residual oil-fired units, and its application ratio is around $20 \%$. From our estimation, the average of $\mathrm{NO}_{\mathrm{x}}$ emission factors for both coal- and natural gas-fired units has decreased by around $70 \%$ over the last two decades, and decreased by $28 \%$ for residual oil-fired units, as shown in Table 3. In addition, $\mathrm{SO}_{2}$ and $\mathrm{NO}_{\mathrm{x}}$ emission factors used in this study are all within the reasonable range of AP-42.

Compared to the trends in energy consumption from power plants in Fig. 3a, trends of $\mathrm{SO}_{2}$ and $\mathrm{NO}_{\mathrm{x}}$ emission estimated in this study are within the constraint of energy evolution (i.e., below the energy trends). Also, the majority of the emissions in this study agree with the original NEI data, except for $\mathrm{NO}_{\mathrm{x}}$ emissions from distillate fuel oil combusted in power plants. The increase during 1996-1999 and 2001-2002 shown in the NEI data is hardly explained by the change in activities, which also means the emission factors during that period do not meet the rules (i.e., any given year it should be no larger than the one for the previous year; and all emission factors should be within the range from AP-42, i.e., equal to or smaller than uncontrolled level, and equal to or greater than the maximally controlled level). The modified emission factors (which were set to be equal to the one for the previous year and within the uncontrolled level) were used in this study; these agree better with the energy trends. The discrepancies in energy and emission trends, evident in the charts for coal-fired units for both $\mathrm{SO}_{2}$ and $\mathrm{NO}_{\mathrm{x}}$, natural gas for $\mathrm{NO}_{\mathrm{x}}$ and oil-fired units for $\mathrm{SO}_{2}$, indicate the progress of emission controls, which was informed by $7 \mathrm{yr}$ of NEI data. Besides, the consumption of natural gas in power plants increased much faster than coal, suggesting that cleaner fuel (i.e., natural gas) was used to replace coal and oil, which resulted in further reduction of emissions (see Fig. 3a; consumption of natural gas increased by $200 \%$ while coal increased by $20 \%$ ).

PM emissions from power plants have been well controlled since 1990. The application ratio of post-combustion control technology (mainly from electrostatic precipitators) reached $90 \%$ of total capacity in coal-fired units in 1990, and further increased to $96 \%$ in 2010 because of the wide application of advanced control technologies like baghouses and electrostatic precipitators (as seen in Fig. S3). Such strengthened control efforts reduced the average of PM emission factors by $27 \%$ for coal-fired power plants.

Since there were no significant controls on $\mathrm{CO}$ and NMVOC, the emissions increased by 53 and $18 \%$ along with the growth in fuel consumption. The increase in $\mathrm{NH}_{3}$ 
(a) Power plant

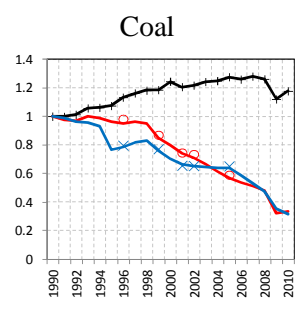

(b) Industrial Combustion

(c) Commercial Combustion

(d) Residential Combustion
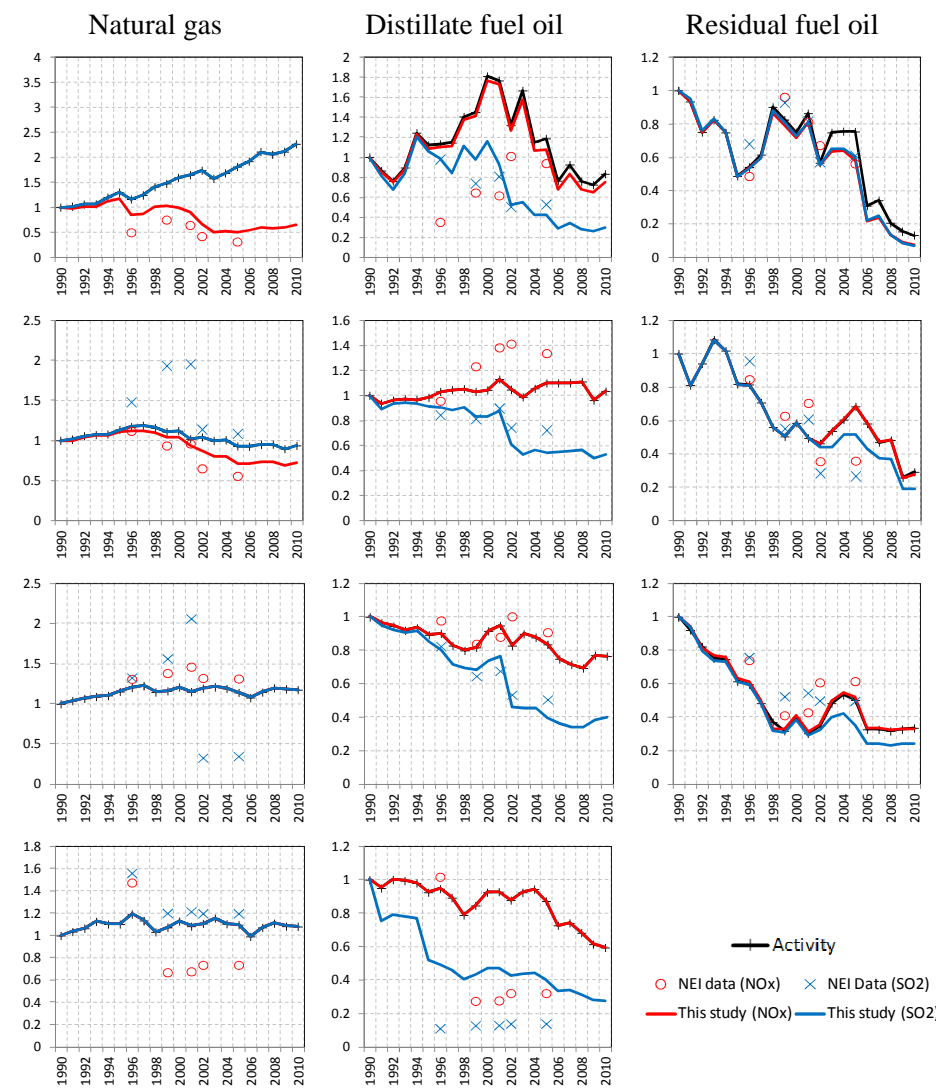

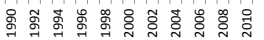

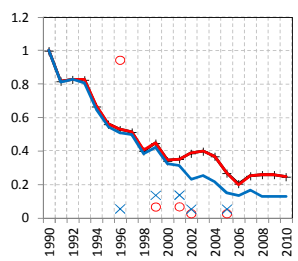

Fig. 3. Activity (fuel use) and $\mathrm{NO}_{\mathrm{x}}$ and $\mathrm{SO}_{2}$ emission trends during 1990-2010 for energy-related stationary sources (year 1990=1; absolute values are provided in Table $\mathrm{S} 2 \mathrm{a})$.

emissions was caused by the application of $\mathrm{NO}_{\mathrm{x}}$ controls (e.g., SCR) that use $\mathrm{NH}_{3}$ or urea.

\subsubsection{Other combustion}

Fuel combustion from industrial, commercial and residential sources accounted for 11 and $14 \%$ of total $\mathrm{NO}_{\mathrm{x}}$ and $\mathrm{SO}_{2}$ emissions in 2002, respectively. Use of low sulfur coal as well as innovative technologies to clean high sulfur were promoted by the Acid Rain Program, resulting in a reduction of average $\mathrm{SO}_{2}$ emission factor in coal-fired boilers by $40-60 \%$. The average $\mathrm{SO}_{2}$ emission factor in oil-fired boilers was also decreased by $30-60 \%$, which was caused by the "spillover effect" from the impact of lowering the sulfur content of highway diesel. $\mathrm{NO}_{\mathrm{x}}$ controls in coal- and natural gas-fired industrial boilers reduced their emission factors by 37 and $23 \%$ respectively, as seen in Table $3 . \mathrm{SO}_{2}$ and $\mathrm{NO}_{\mathrm{x}}$ emission factors used in this study are all within the reasonable range of AP-42.

As seen in Fig. 3b-d, $\mathrm{SO}_{2}$ and $\mathrm{NO}_{\mathrm{x}}$ emission trends estimated in this study are better constrained by energy trends than that in the NEI data. For example, the $\mathrm{SO}_{2}$ emission from industrial natural gas combustion increased by $100 \%$ from 1990 to 2000 in NEI, which is doubtful because the energy consumption only increased by $20 \%$ during that period. Similar excessive increases in NEI are also shown in $\mathrm{NO}_{\mathrm{x}}$ emissions in 2000-2005 industrial distillate fuel combustion and 2000-2002 commercial coal combustion. This suggests that the emission factors during that period do not meet the rules (i.e., any given year it should be no larger than the one for the previous year). Besides, the residential $\mathrm{NO}_{\mathrm{x}}$ emissions decreased sharply from 1996 to 1999 in NEI data. Information about such reduction is unavailable, so in our estimates we followed the rule (i.e., if there is no evidence of controls, a consistent emission factor should be applied to all years during the study period) to modify the trends of residential $\mathrm{NO}_{\mathrm{x}}$ emissions to be the same as the trends in energy.

Though the control effort taken in these combustion sectors is not as much as that in the power sector, all pollutant emissions from other combustion sources were significantly reduced, mainly caused by the decline in consumption of coal and oil, which were replaced by cleaner fuels like natural gas.

\subsubsection{On-road mobile sources}

On-road transportation is one of the most important emission sources, contributing 41, 68 and $31 \%$ to total anthropogenic $\mathrm{NO}_{\mathrm{x}}, \mathrm{CO}$ and NMVOC emissions in 2002, respectively. 

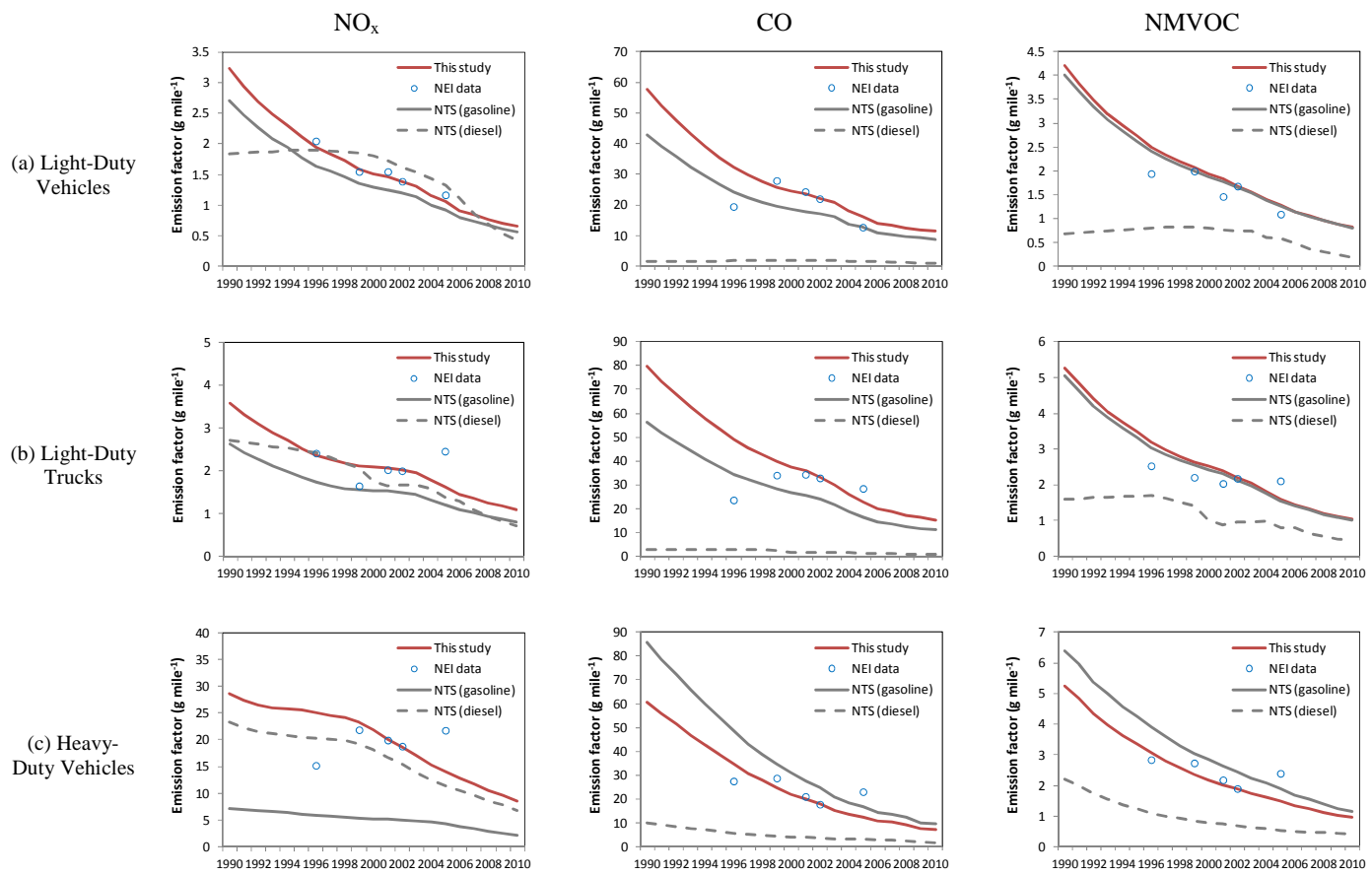

Fig. 4. On-road $\mathrm{NO}_{\mathrm{x}}, \mathrm{CO}$ and $\mathrm{NMVOC}$ emission factors in this study (NTS - National Transportation Statistics).

Light-duty vehicles and trucks, which have a larger vehicle population, contribute more to $\mathrm{CO}$ and NMVOC emissions, while heavy-duty vehicles and trucks, the majority of which are powered by compression ignition engines using diesel fuel, contribute a comparable percentage as light-duty vehicles and trucks to $\mathrm{NO}_{\mathrm{x}}$ emissions because of their higher $\mathrm{NO}_{\mathrm{x}}$ emission factor that is 5-10 times higher than that of light-duty vehicles and trucks, as shown in Table $1 b$.

As shown in Fig. 4, along with the progress in strengthening the federal exhaust emissions certification standards for newly manufactured vehicles starting from 1970s (see Fig. S4), the average emission factors of $\mathrm{NO}_{\mathrm{x}}, \mathrm{CO}$ and NMVOC in highway transportation significantly decreased by $80 \%$ between 1990 and 2010. Besides, all the emission factors used in this study are within the range between the current standards and the one about $20 \mathrm{yr}$ ago (assuming the vehicle lifetime was about $20 \mathrm{yr}$ ), and exhibit comparable values but a smoother decline (agreed well with the estimated national average emission rates in 2011 National Transportation Statistics) compared to those calculated from NEI data. Particularly, $\mathrm{NO}_{\mathrm{x}}$ emission factors of light-duty trucks and heavy-duty vehicles and trucks in $2005 \mathrm{NEI}$ are much higher than those in 2002 NEI, which was caused by the method change from MOBILE to MOVES.

Though highway transportation accounts for only a small part of total $\mathrm{SO}_{2}$ and $\mathrm{PM}$ emissions (about $2 \%$ ), efforts have been made by US EPA to lower the sulfur content of diesel oil used for transportation in the 1990s, as well as to reduce on-road dust emissions (Dallmann and Harley, 2010).
As seen from the comparison of emission and activity (i.e., VMT) trends in Fig. 5, our estimations agree well with NEI data. With strengthened control efforts, all pollutants (except $\mathrm{NH}_{3}$ ) exhibit declining trends despite a growth of activity for all types of vehicles. The on-road $\mathrm{NO}_{\mathrm{x}}$ emission was decreased by $58 \%$, which is close to the NEI trends data of $55 \%$. McDonald et al. (2012) suggested relatively lower reduction ratio as $33 \%$. That is mainly because, in the McDonald et al. (2012) study, the reduction in $\mathrm{NO}_{\mathrm{x}}$ emission factor for heavy-duty diesel vehicles is about $36 \%$, which is relatively smaller than the one suggested by National Transportation statistics of $70 \%$.

\subsubsection{Off-road mobile sources}

Off-road transportation is another important emission source for $\mathrm{NO}_{\mathrm{x}}, \mathrm{CO}$ and $\mathrm{NMVOC}(17,12$ and $11 \%$ respectively). $\mathrm{NO}_{\mathrm{x}}$ emissions are primarily attributable to diesel-powered engines, including off-road transportation, rail and marine vessels, which have higher emission factors, while $\mathrm{CO}$ and NMVOC are largely attributable to gasoline-powered equipment (see in Table 1b). The emission factors used in this study are comparable to those in GAINS (see in Table 3), as well as the studies on US mobile emissions from 1996 to 2006 by Dallmann and Harley (2010), suggesting that the activity we selected and emission factor we calculated in this study are suitable to use. 


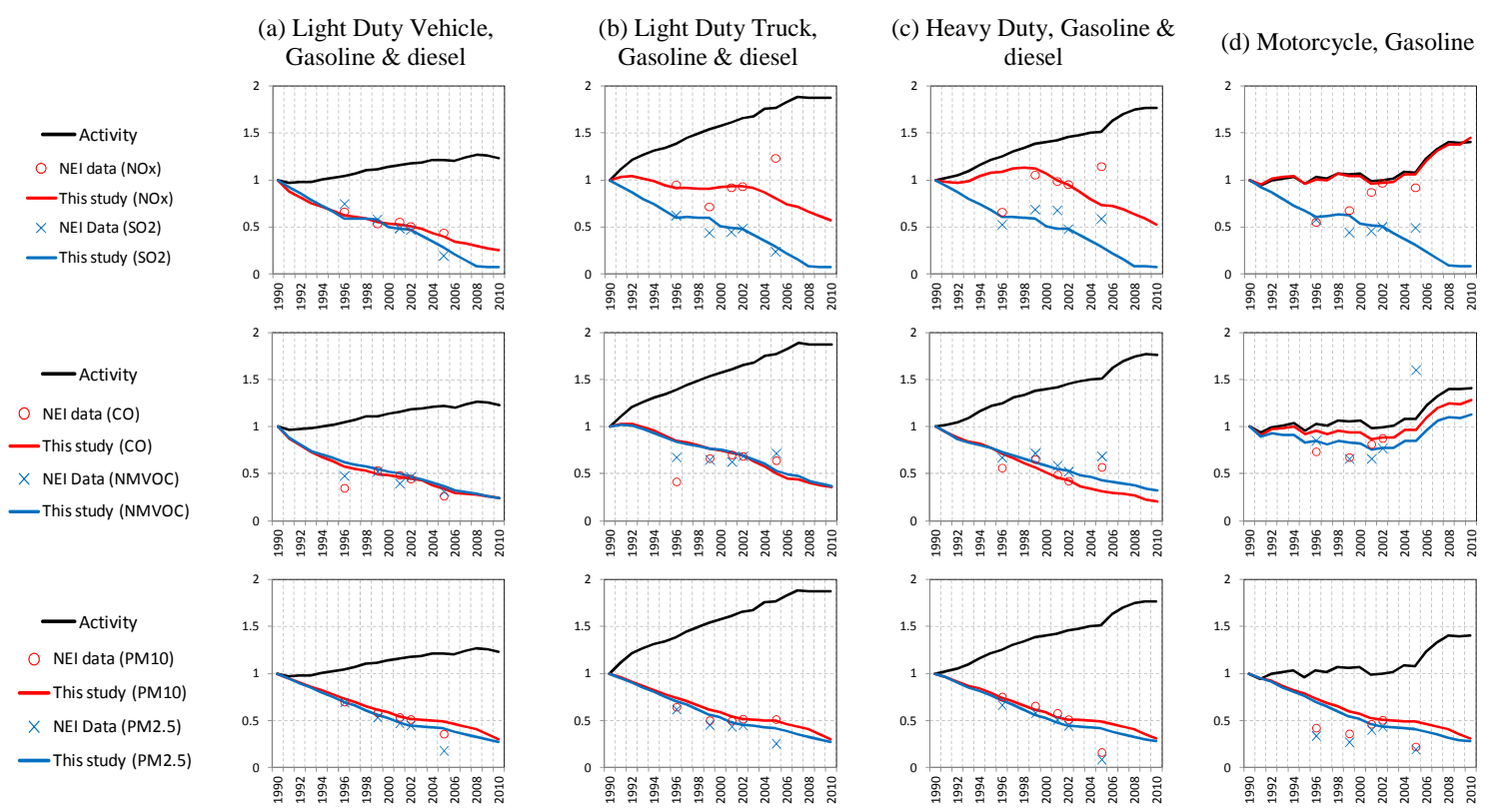

Fig. 5. Activity and emission trends during 1990-2010 for on-road mobile sources (year 1990=1; absolute values are provided in Table S2b).
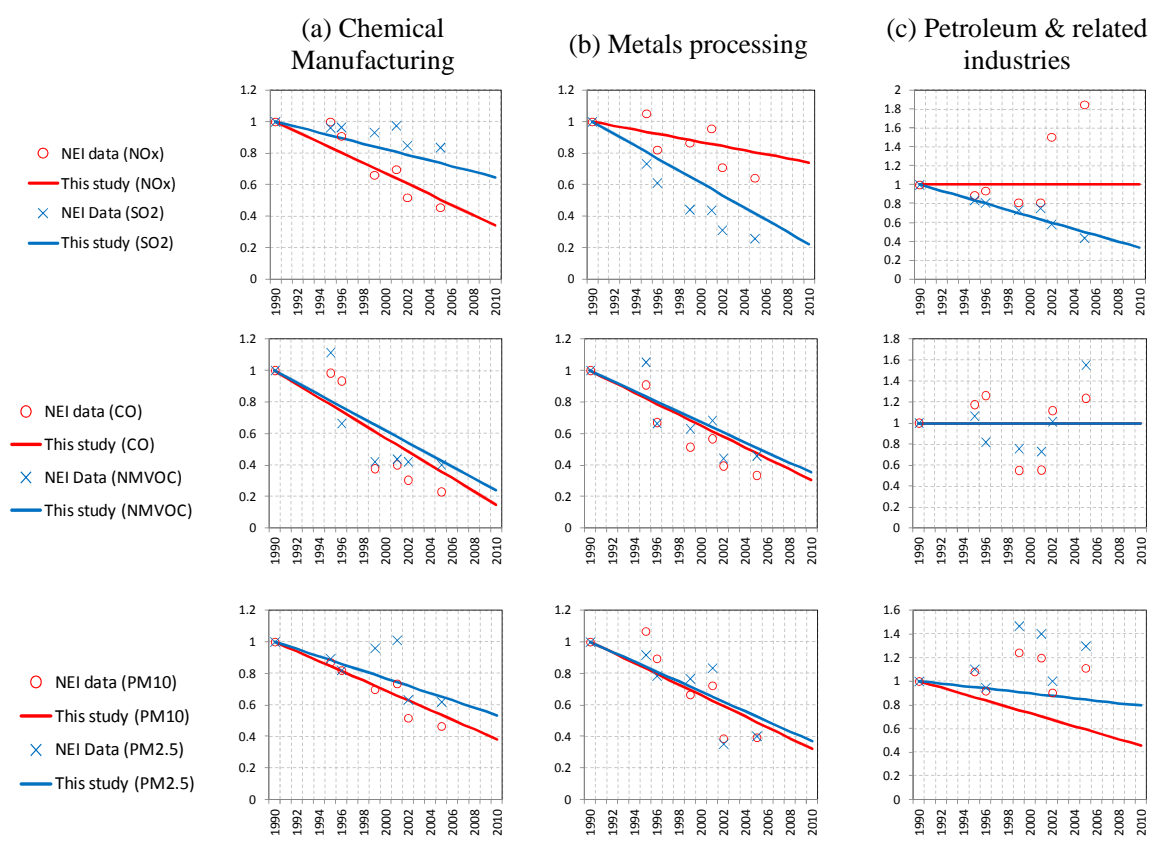

(d) Other industry processes
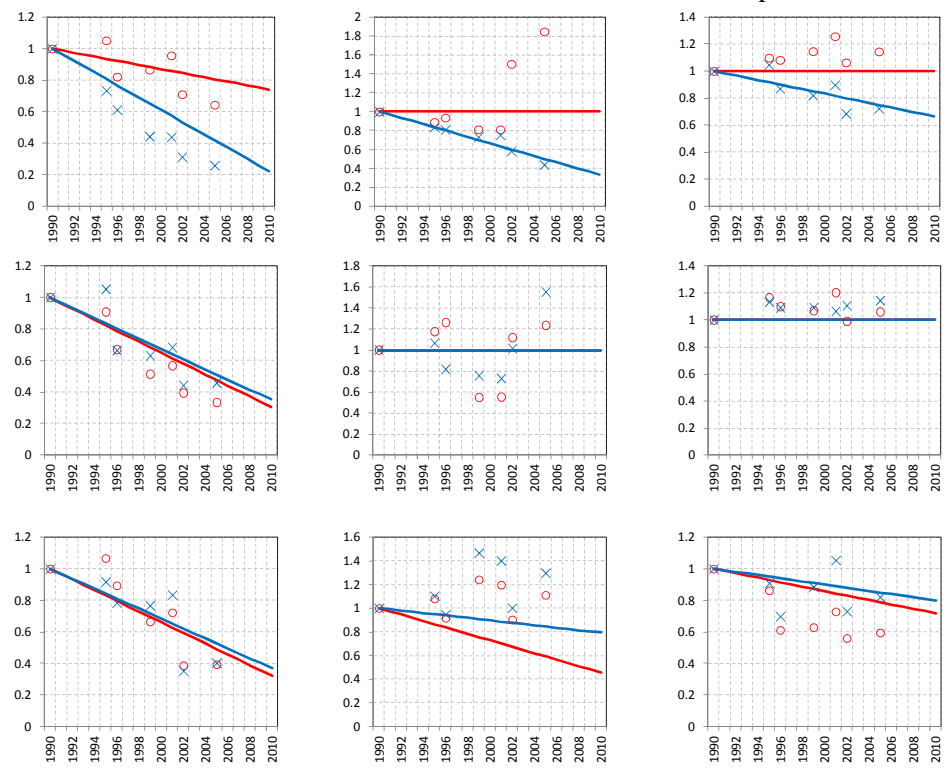

Fig. 6. Emission trends during 1990-2010 for industrial process sources (year 1990=1; absolute values are provided in Table S2c).

\subsubsection{Non-energy-related sources}

Emissions from industrial processes were processed by using a linear fit method calculated from NEI trends, as shown in Fig. 6. Significant reductions by $20-80 \%$ are found in sectors such as chemical manufacturing and metals processing for all pollutants. The linear-fit trends in this study roughly agree well with NEI trends. However, since it is extremely difficult to obtain activity indicators for each of those numer- ous processes over such an extended time period, the trend estimates for these sectors are highly uncertain and warrant further investigation.

Each of the other non-energy-related sources typically contributes to one or two specific pollutant, as shown in Fig. 7. $\mathrm{NH}_{3}$ emissions from fertilizer applications and $\mathrm{PM}$ emissions from mining and quarrying, and forest wildfires increased significantly in NEI data, even larger than the activity trend. Those emissions were scaled by growth ratios of 


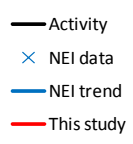

(e) Mining \& quarrying $\left(\mathrm{PM}_{10}\right)$

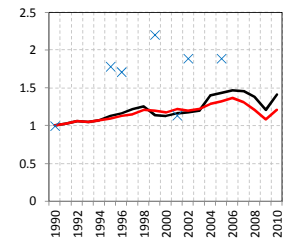

(a) Solvent utilization (NMVOC)

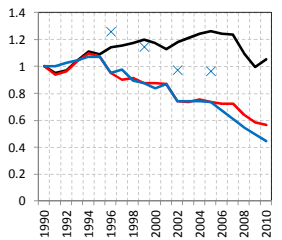

(f) Paved/Unpaved road $\left(\mathrm{PM}_{10}\right)$

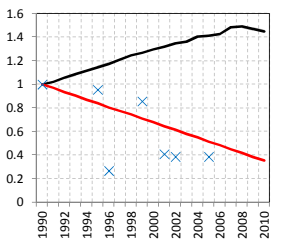

(b) Fertilizer Application

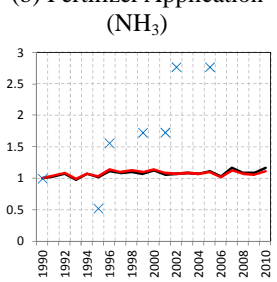

(g) Agriculture tilling $\left(\mathrm{PM}_{10}\right)$

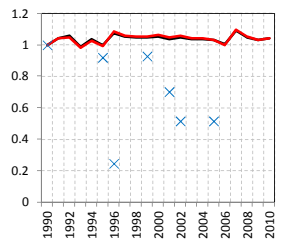

(c) Livestock $\left(\mathrm{NH}_{3}\right)$

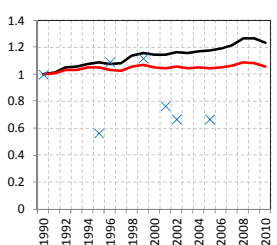

(h) Forest wildfires $\left(\mathrm{PM}_{10}\right)$

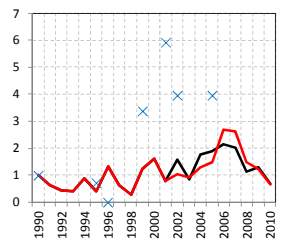

(d) Construction processes $\left(\mathrm{PM}_{10}\right)$

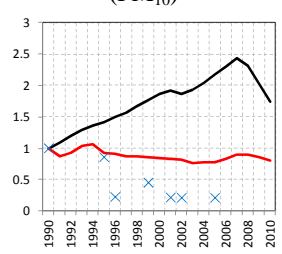

(i) Prescribed Forest Management $\left(\mathrm{PM}_{10}\right)$

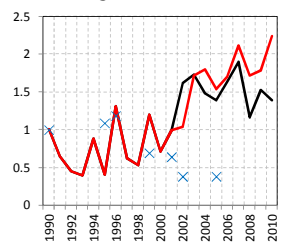

Fig. 7. Activity and emission trends during 1990-2010 for other non-energy-related sources (year 1990=1; absolute values are provided in Table S2d).

corresponding activities alone without controls. Compared to the trends of activity data, though NEI data presented decrease in several sectors including livestock $\mathrm{NH}_{3}$ and $\mathrm{PM}$ from agriculture tilling and prescribed forest management, information about such decreases is unavailable, so those emissions were also scaled by growth ratios of corresponding activities.

The declining trends evident in VOC emissions from solvent utilization, PM emissions from construction processes, and paved/unpaved road dust shown in NEI data suggest that control efforts have been made in these sectors. Thus their emissions were additionally adjusted based on NEI data.

\subsection{Comparison and validation}

Table 4 summarizes the changes in total emissions from 1990 to 2010. Significant reductions are shown for $\mathrm{SO}_{2}, \mathrm{NO}_{\mathrm{x}}$, $\mathrm{CO}, \mathrm{NMVOC}, \mathrm{PM}_{10}$ and $\mathrm{PM}_{2.5}$; these reductions are 67 , 48, 60\%, 48, 50 and $34 \%$ respectively. Most sectors contribute to these reductions. Strengthened controls on power plants are the dominant factor for $\mathrm{SO}_{2}$ reductions and are also one of the major contributors to $\mathrm{NO}_{\mathrm{x}}$ reductions. Controls on mobile sources largely contribute to the reductions of $\mathrm{NO}_{\mathrm{x}}, \mathrm{CO}$ and NMVOC emissions. The reductions in PM emissions are mainly from the controls on the on-road dust sources. Seen from the spatial distribution of those changes presented in Fig. 8, those reductions were widely distributed over the US, but much more strengthened in the north area and California where emission intensities were higher. Due to the growth of livestock activities, $\mathrm{NH}_{3}$ emissions were increased by $11 \%$, particularly in North Carolina and Iowa due to significant increases in the activity of livestock and agriculture. The growth of application of $\mathrm{NO}_{\mathrm{x}}$ controls (e.g., $\mathrm{SCR}$ ), which use $\mathrm{NH}_{3}$-rich material as the reducing agent, also contributes some to the $\mathrm{NH}_{3}$ increases.
The $20 \mathrm{yr}$ emissions calculated in this study were compared with NEI trends and EDGAR data, as seen in Fig. 9. In general, the results of this study agree well with the other two trends, particularly for $\mathrm{SO}_{2}$. Relatively lower emissions were shown in EDGAR for $\mathrm{NO}_{\mathrm{x}}, \mathrm{CO}, \mathrm{VOC}$ and PM. The emission trends developed in this study are closer to NEI trends, but with a smoother trend.

The trends of $\mathrm{SO}_{2}, \mathrm{NO}_{\mathrm{x}}, \mathrm{CO}$ and $\mathrm{EC}$ emissions were compared with the observed trends in ambient surface $\mathrm{SO}_{2}, \mathrm{NO}_{2}$, $\mathrm{CO}$ and EC concentrations to evaluate the $20 \mathrm{yr}$ of emission inventories. The spatial distributions of trends generally agree well with the observations, as seen in Fig. 10a. The results indicate that the declining emission trends manifest themselves in decreasing observed concentrations for all species, and that those reductions were widely distributed across the whole continental US domain. The average reductions of $\mathrm{SO}_{2}, \mathrm{NO}, \mathrm{CO}$ and $\mathrm{EC}$ emissions in the grid cells near monitors are $69,47,58$ and $36 \%$ respectively, which agrees well with the observed decrease of $\mathrm{SO}_{2}, \mathrm{NO}_{2}, \mathrm{CO}$ and $\mathrm{EC}$ concentrations, as 63, 33, 71 and $50 \%$, respectively.

As seen in Fig. 10b, emission trends of $\mathrm{SO}_{2}, \mathrm{NO}, \mathrm{CO}$ and $\mathrm{EC}$ are given by sector (the same as the one defined in SMOKE): (1) ptipm - NEI point source EGUs (electric generating units) mapped to the Integrated Planning Model using the National Electric Energy Database System; (2) ptnonipm - all NEI point source records not matched to the ptipm sector; (3) mobile; (4) non-road; and (5) other area sources. It can be seen that deceases in different species were driven by reductions in different source sectors. At the national level, EGUs are the dominant source of $\mathrm{SO}_{2}$. The trend of observed $\mathrm{SO}_{2}$ concentration closely follows the EGU trend, with decreases during the period of 1990-1995 and after 1998 and increases during the period of 1995-1998. Since the dominant sources may be different at different locations, we also conducted the comparison at a sub-regional scale. 
Table 4. Sector-specific emissions in the United States for 1990 and 2010 estimated in this study (unit: $\mathrm{Gg} \mathrm{yr}^{-1}$ ).

\begin{tabular}{|c|c|c|c|c|c|c|c|c|c|c|c|c|c|c|c|c|c|c|c|c|c|}
\hline \multirow{2}{*}{ Sector } & \multicolumn{3}{|c|}{$\mathrm{SO}_{2}$} & \multicolumn{3}{|c|}{$\mathrm{NO}_{\mathrm{x}}$} & \multicolumn{3}{|c|}{$\mathrm{CO}$} & \multicolumn{3}{|c|}{ NMVOC } & \multicolumn{3}{|c|}{$\mathrm{PM}_{10}$} & \multicolumn{3}{|c|}{$\mathrm{PM}_{2.5}$} & \multicolumn{3}{|c|}{$\mathrm{NH}_{3}$} \\
\hline & 1990 & 2010 & $\Delta$ & 1990 & 2010 & $\Delta$ & 1990 & 2010 & $\Delta$ & 1990 & 2010 & $\Delta$ & 1990 & 2010 & $\Delta$ & 1990 & 2010 & $\Delta$ & 1990 & 2010 & $\Delta$ \\
\hline Power plants & 16117 & 5018 & $-69 \%$ & 6431 & 2237 & $-65 \%$ & 294 & 462 & $57 \%$ & 39 & 46 & $20 \%$ & 654 & 559 & $-15 \%$ & 529 & 462 & $-13 \%$ & 11 & 19 & $70 \%$ \\
\hline Other Comb. & 3764 & 1215 & $-68 \%$ & 2625 & 1772 & $-32 \%$ & 4686 & 2598 & $-45 \%$ & 841 & 428 & $-49 \%$ & 1048 & 511 & $-51 \%$ & 767 & 389 & $-49 \%$ & 26 & 28 & $6 \%$ \\
\hline On-road & 499 & 35 & $-93 \%$ & 10972 & 4643 & $-58 \%$ & 136586 & 38627 & $-72 \%$ & 9798 & 2828 & $-71 \%$ & 392 & 118 & $-70 \%$ & 333 & 92 & $-72 \%$ & 145 & 276 & $91 \%$ \\
\hline Off-road & 619 & 452 & $-27 \%$ & 3428 & 2768 & $-19 \%$ & 12257 & 11870 & $-3 \%$ & 2388 & 1950 & $-18 \%$ & 245 & 188 & $-23 \%$ & 222 & 172 & $-22 \%$ & 2 & 2 & $-21 \%$ \\
\hline Ind. Process & 2147 & 873 & $-59 \%$ & 1412 & 1227 & $-13 \%$ & 5498 & 2133 & $-61 \%$ & 2291 & 1686 & $-26 \%$ & 637 & 318 & $-50 \%$ & 469 & 287 & $-39 \%$ & 126 & 126 & $0 \%$ \\
\hline Other & 100 & 104 & $5 \%$ & 390 & 400 & $2 \%$ & 12922 & 12992 & $1 \%$ & 8450 & 5277 & $-38 \%$ & 17130 & 8394 & $-51 \%$ & 3814 & 2675 & $-30 \%$ & 3181 & 3414 & $7 \%$ \\
\hline All & 23246 & 7697 & $-67 \%$ & 25258 & 13048 & $-48 \%$ & 172243 & 68682 & $-60 \%$ & 23807 & 12215 & $-49 \%$ & 20105 & 10088 & $-50 \%$ & 6134 & 4077 & $-34 \%$ & 3491 & 3864 & $11 \%$ \\
\hline
\end{tabular}

Note: $\Delta=\left(\right.$ Emis $_{2010}-$ Emis $\left._{1990}\right) /$ Emis $_{1990} \times 100 \%$.
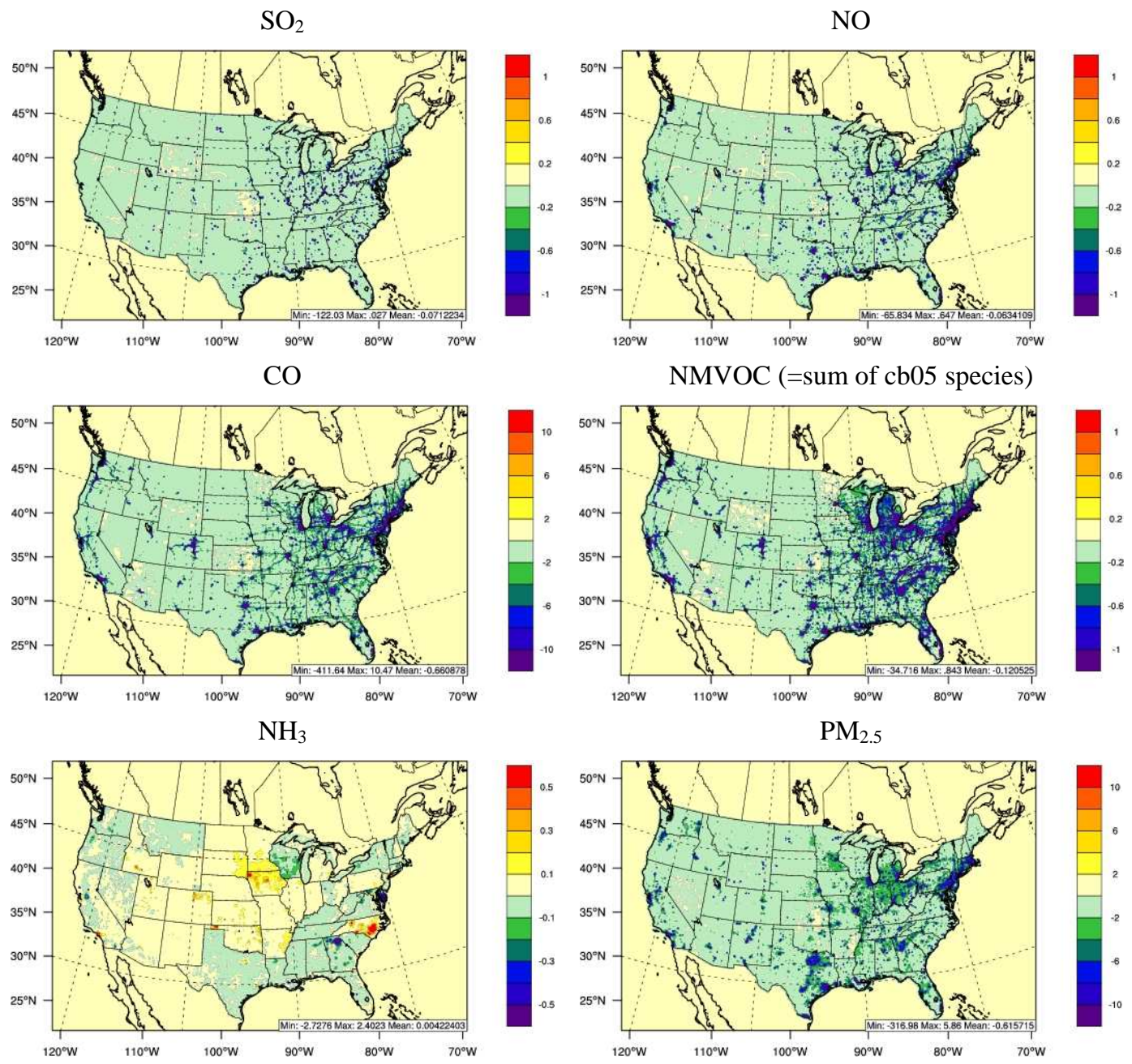

Fig. 8. Changes in emission rates over the $12 \mathrm{~km} \times 12 \mathrm{~km}$ CONUS domain from 1990 to 2010 (unit: moles s$^{-1}$ grid for gaseous species, $\mathrm{g} \mathrm{s}^{-1}$ grid for $\mathrm{PM}_{2.5}$ ).

The sub-regions used in this analysis were the same as defined in Hand et al. (2012): West, Great Plains, Southwest, Northeast, Midsouth and Southeast (as shown in Fig. 11).

For $\mathrm{SO}_{2}$ (see Fig. 12a), the comparisons for the Northeast, Midsouth and Southeast show similar results as the analysis at the national level. The decrease in emission trends after 2006 is $10-30 \%$ larger than that in observed trends. EGU is also the dominant source in the southwest area, but its re- duction is more significant after 1998. In the West and the Great Plains, the comparison is not as good as the other regions. In the West, non-EGU point and area sources are the dominant sources. Emissions generally present similar decreasing trends, but the decrease in emission trends after 2006 is $10-30 \%$ smaller than that in the observed trend. In the Great Plains, $\mathrm{SO}_{2}$ emission was dominated by non-EGU point sources. Though a decreasing trend was shown in both 

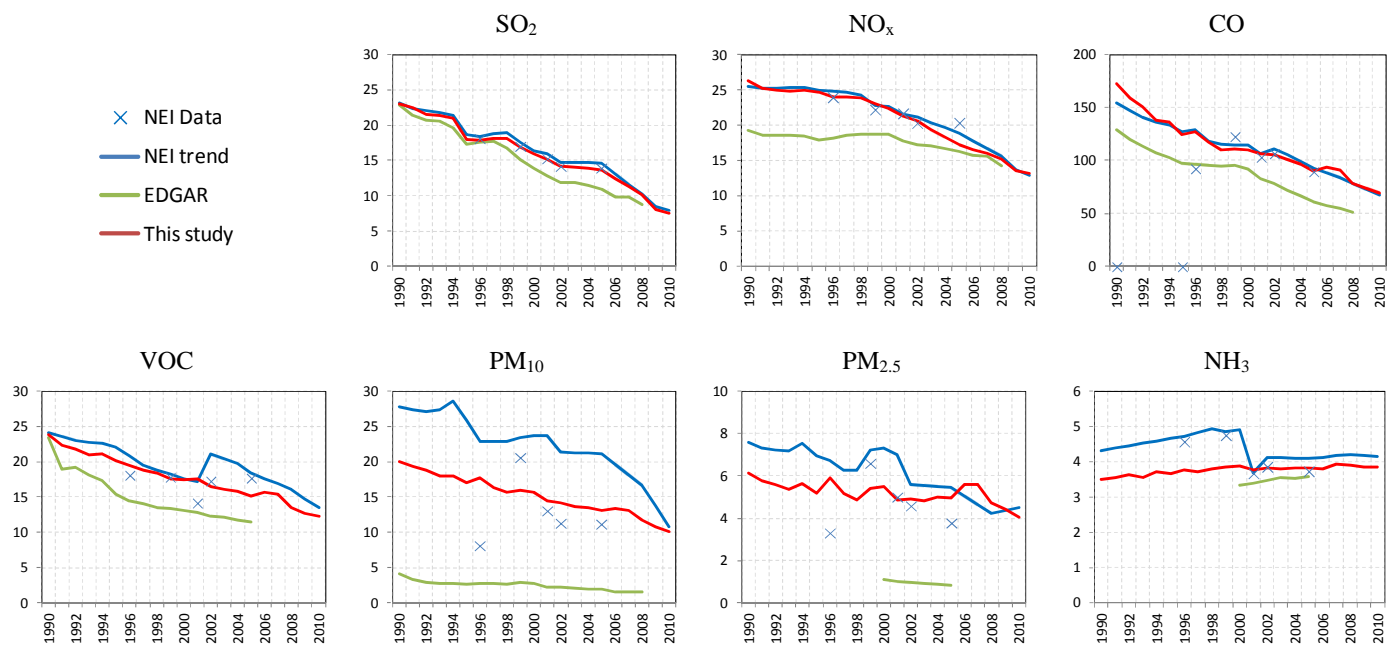

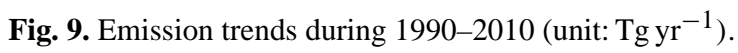

a. (Year 2010 - Year 1990) / Year 1990

Obs.
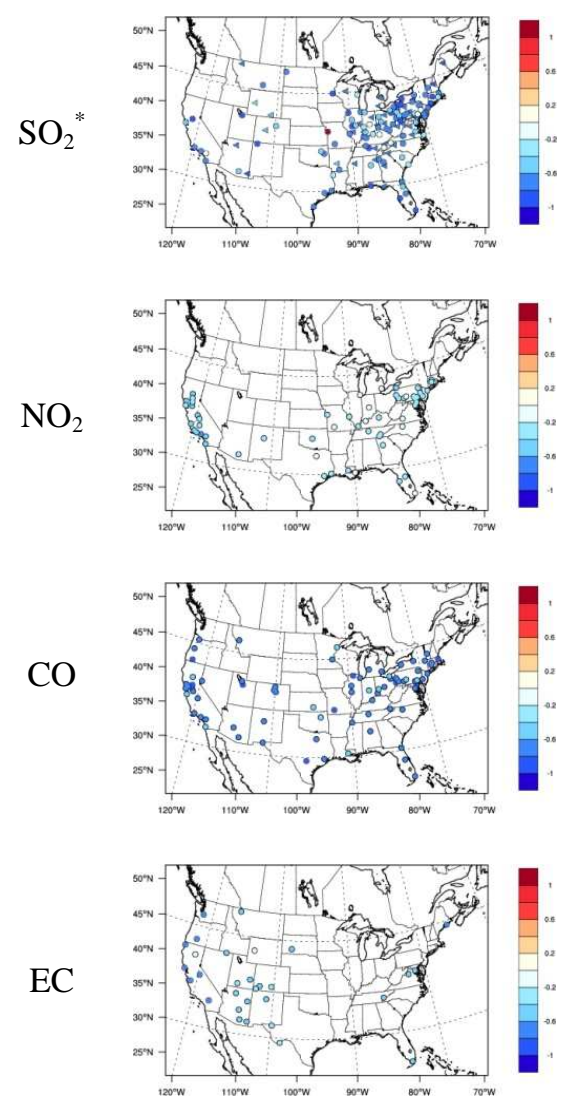

Emi.
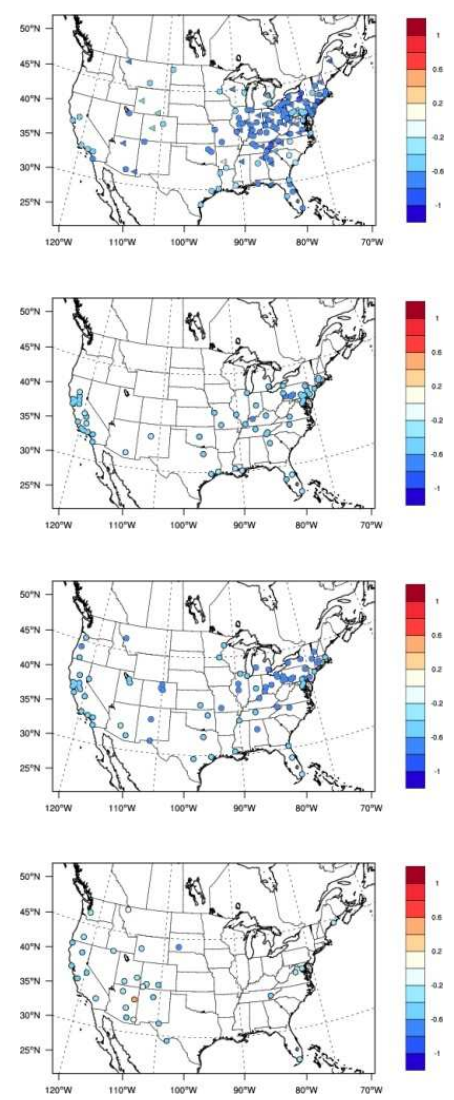

b. Average of all sites ${ }^{* *}$

(Annual mean)
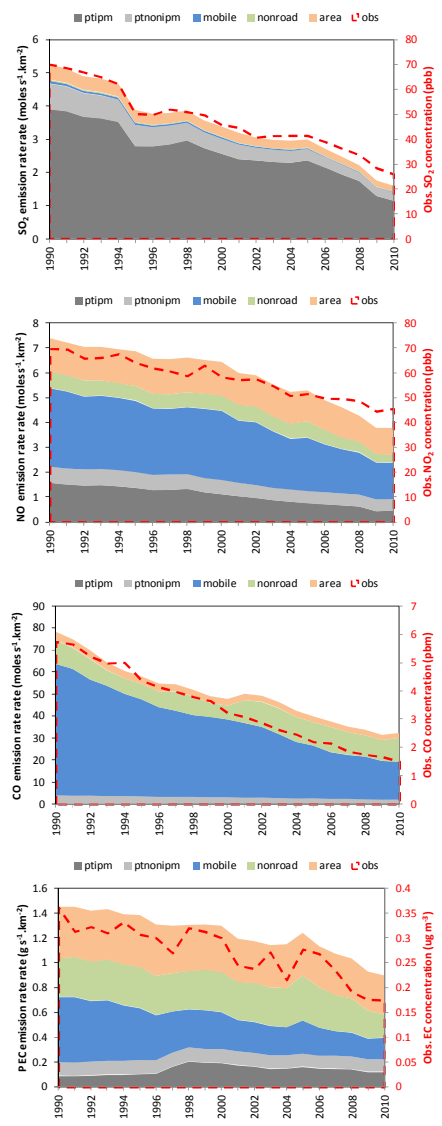

Fig. 10. Comparison of historic trends between emissions and observed concentration from 1990 to 2010 (* for $\mathrm{SO}_{2}$, circles represent AQS sites; triangles represent CASTNET sites; ${ }^{* *}$ SMOKE sectors include (1) ptipm - NEI point source EGUs mapped to the Integrated Planning Model using the National Electric Energy Database System; (2) ptnonipm - all NEI point source records not matched to the ptipm sector; (3) mobile; (4) non-road and (5) other area sources). 


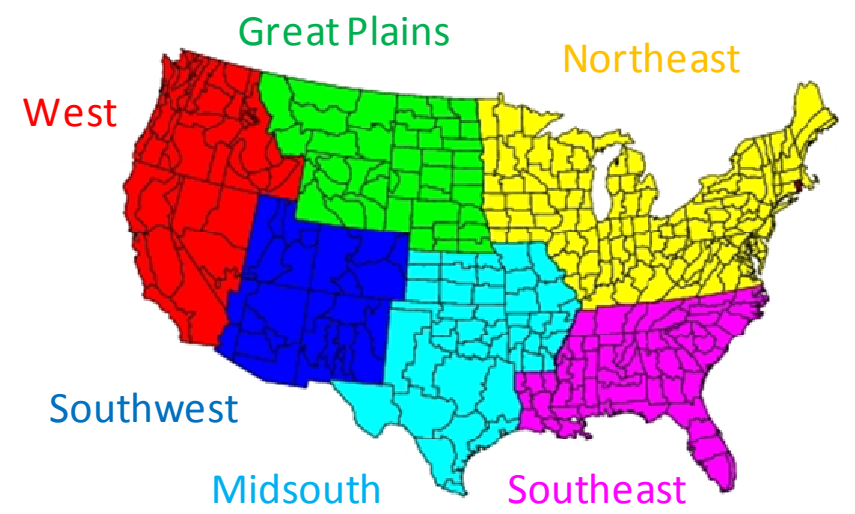

Fig. 11. Definition of sub-regions used in analysis.

emissions and observed concentrations, the $\mathrm{SO}_{2}$ concentration before 1996 is extremely high but the $\mathrm{SO}_{2}$ emission rate is even lower than in other regions. Some important sources in that area may be missing during that period (the baseline inventory is more recent and may not include sources that are now shut off).

Mobile sources are the dominant contributor to $\mathrm{NO}_{\mathrm{x}}$ emissions in all regions (see Fig. 12b). The national emission trend agrees better with the trends of observed $\mathrm{NO}_{2}$ concentration before 2000 than with the trends after 2000 . The decrease in emission trends after 2000 is $10-20 \%$ smaller than that in observed trends. Similar results are also found in the Northeast, Midsouth and Southeast. $\mathrm{NO}_{\mathrm{x}}$ reductions in mobile sources may be over-predicted by $10-20 \%$ in those areas. In the West and Southwest, observed trends during 1997-2006 are 10-20\% lower than the emission trends, which suggests that $\mathrm{NO}_{\mathrm{x}}$ mobile controls in those regions may be several years ahead of the nation level. Further improvement of this study may consider using different trends of mobile emission factors for different regions.

Mobile is also the dominant $\mathrm{CO}$ emissions source for all regions (see Fig. 12c). The national emission trend agrees well with observed CO concentration before 1999, but 10$30 \%$ higher after 2000. The trends of mobile CO emission factors might under-predict the control effectiveness after 2000, particularly in the West region.

EC emissions are contributed by various sources. The observed trend is more variable than other species, suggesting that the changes of meteorological conditions and wildfire activity may contribute to that variation. However, the EC emission trend roughly agrees with the observed trend of EC concentration. Such a decrease is mainly driven by the reduction in mobile sources.
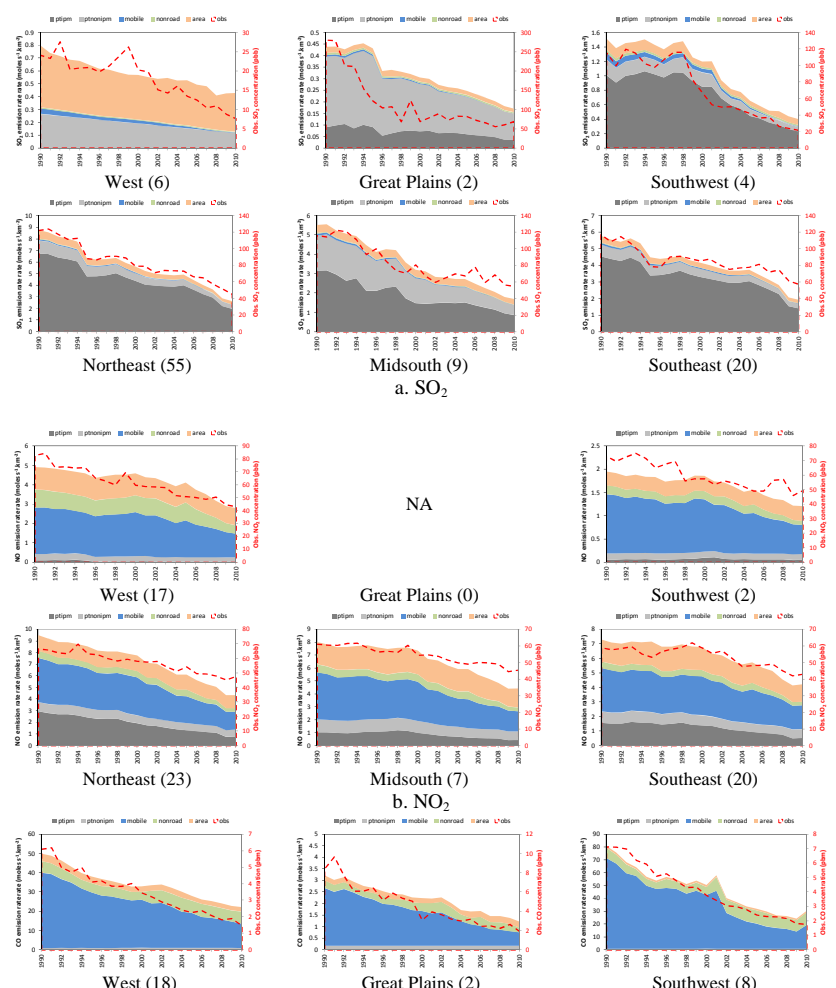

Great Plains (2)
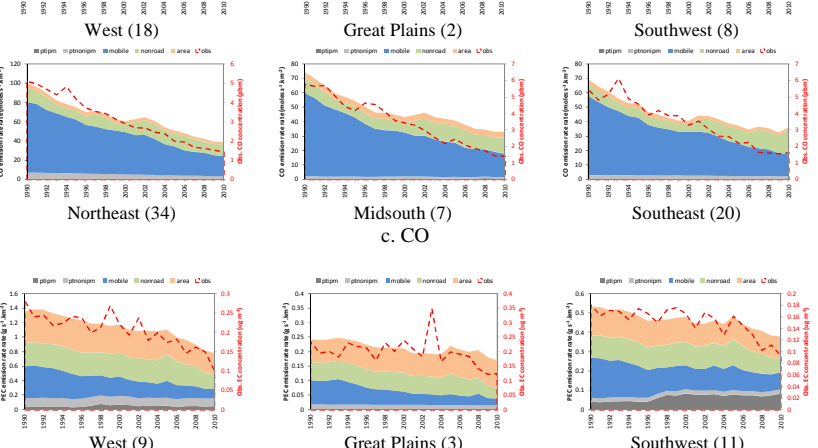

Great Plains (3)

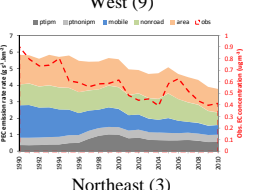

Northeast (3)
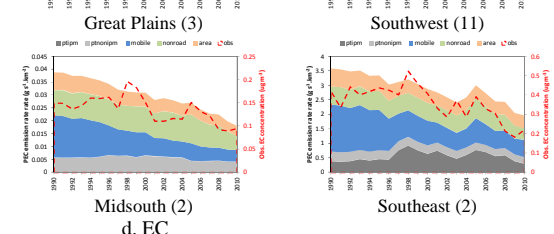

Fig. 12. Comparison of historic trends between emissions and observed concentration from 1990 to 2010 by sector and region (number of sites are shown in brackets).

\section{Conclusions}

A consistent series of spatially resolved anthropogenic emissions of $\mathrm{SO}_{2}, \mathrm{NO}_{\mathrm{x}}, \mathrm{CO}, \mathrm{NMVOC}, \mathrm{NH}_{3}, \mathrm{PM}_{10}$ and $\mathrm{PM}_{2.5}$ in the United States from 1990 to 2010 was developed by using an approach based on several long-term databases containing information about changes in activity data and emission controls. These inventories were processed by SMOKE and are ready to be used for regional chemistry transport model simulations. 
The set of inventories developed in this study is internally consistent, constrained by activity trends, within reasonable range of emissions and controls, and comparable with previous studies. However, due to the lack of a detailed historic record of control information over such an extended time period (except for the power sector), our estimations on control efforts for other sectors highly depended on NEI data or NEI trends. Besides, since this study mainly focused on trends rather than the absolute value in each individual year, some sectors (e.g., industrial processes) and sub-sectors (types of combustion and stoves) may not have been well considered or examined. For example, Heald et al. (2012) suggested that ammonia emissions in 2005 NEI (which they used for their simulations) are underestimated in California and in the springtime in the Midwest. Since the new emission inventory is based on 2005 NEI, it may also suffer such underestimation. Therefore, future improvement in the accuracy of baseline emission inventory (i.e., 2005 NEI in this study) is also necessary. Mobile emissions were only based on MOBILE6 results rather than the newly developed MOVES module. Further improvement on those details is still necessary.

\section{Supplementary material related to this article is available online at: http://www.atmos-chem-phys.net/13/ 7531/2013/acp-13-7531-2013-supplement.pdf.}

Acknowledgements. Although this work has been reviewed and approved for publication by the US Environmental Protection Agency (EPA), it does not reflect the views and policies of the agency. This work was supported by department of energy project (IA number is DE-SC000378) and EPA (IA number is RW-89-9233260 1). This research was performed while the author held a National Research Council Research Associateship Award at US EPA. The authors also acknowledge the free use of EDGAR, NEI, GAINS, State Energy Data System, Department of Agriculture National Agricultural Statistics Service and Air Markets Program Data.

Edited by: R. Harley

\section{References}

Adelman, Z. and Houyoux M.: Processing the National Emissions Inventory 96 (NEI96) version 3.11 with SMOKE, presented at the Emission Inventory Conference: One Atmosphere, One Inventory, Many Challenges, 1-3 May, Denver, CO, 2001.

Bookhart, D. and Zien, K.: "Low Sulfur Heating Oil: Evaluating the Impacts on Consumers," Consumer Energy Council of America, September, 2003

Dallmann, T. R. and Harley, R. A.: Evaluation of mobile source emission trends in the United States, J. Geophys. Res., 115, D14305, doi:10.1029/2010JD013862, 2010.

European Commission: Joint Research Centre (JRC)/Netherlands Environmental Assessment Agency (PBL). Emission Database for Global Atmospheric Research (EDGAR), release version 4.2., available at: http://edgar.jrc.ec.europa.eu, 2011.
Hand, J. L., Schichtel, B. A., Malm, W. C., and Pitchford, M. L.: Particulate sulfate ion concentration and $\mathrm{SO}_{2}$ emission trends in the United States from the early 1990s through 2010, Atmos. Chem. Phys., 12, 10353-10365, doi:10.5194/acp-1210353-2012, 2012.

Heald, C. L., J. L. Collett Jr., Lee, T., Benedict, K. B., Schwandner, F. M., Li, Y., Clarisse, L., Hurtmans, D. R., Van Damme, M., Clerbaux, C., Coheur, P.-F., Philip, S., Martin, R. V., and Pye, H. O. T.: Atmospheric ammonia and particulate inorganic nitrogen over the United States, Atmos. Chem. Phys., 12, 10295-10312, doi:10.5194/acp-12-10295-2012, 2012.

Hogrefe, C., Lynn, B., Goldberg, R., Rosenzweig, C., Zalewsky, E., Hao, W., Doraiswamy, P., Civerolo, K., Ku, J.-Y., Sistla, G., and Kinney, P. L.: A combined model-observation approach to estimate historic gridded fields of $\mathrm{PM}_{2.5}$ mass and species concentrations, Atmos. Environ., 43, 2561-2570, 2009.

Kean, A. J., Sawyer, R. F., and Harley, R. A.: A fuel - based assessment of off - diesel engine emissions, J. Air Waste Manage. Assoc., 50, 1929-1939, 2000.

Lamarque, J.-F., Bond, T. C., Eyring, V., Granier, C., Heil, A., Klimont, Z., Lee, D., Liousse, C., Mieville, A., Owen, B., Schultz, M. G., Shindell, D., Smith, S. J., Stehfest, E., Van Aardenne, J., Cooper, O. R., Kainuma, M., Mahowald, N., McConnell, J. R., Naik, V., Riahi, K., and van Vuuren, D. P.: Historical (1850-2000) gridded anthropogenic and biomass burning emissions of reactive gases and aerosols: methodology and application, Atmos. Chem. Phys., 10, 7017-7039, doi:10.5194/acp10-7017-2010, 2010.

Lindhjem, C. E., Pollack, A. K., DenBleyker, A., and Shaw S. L.: Effects of improved spatial and temporal modeling of on-road vehicle emissions, J. Air Waste Manag. Assoc., 62, 471-484, doi:10.1080/10962247.2012.658955, 2012.

Lu, Z., Streets, D. G., Zhang, Q., Wang, S., Carmichael, G. R., Cheng, Y. F., Wei, C., Chin, M., Diehl, T., and Tan, Q.: Sulfur dioxide emissions in China and sulfur trends in East Asia since 2000, Atmos. Chem. Phys., 10, 6311-6331, doi:10.5194/acp-106311-2010, 2010.

McDonald, B. C., Dallmann, T. R., Martin, E. W., and Harley, R. A.: Long-term trends in nitrogen oxide emissions from motor vehicles at national, state, and air basin scales, J. Geophys. Res., 117, D00V18, doi:10.1029/2012JD018304, 2012.

Smith, S. J., van Aardenne, J., Klimont, Z., Andres, R. J., Volke, A., and Delgado Arias, S.: Anthropogenic sulfur dioxide emissions: 1850-2005, Atmos. Chem. Phys., 11, 1101-1116, doi:10.5194/acp-11-1101-2011, 2011.

Stern, D. I.: Reversal of the trends in global anthropogenic sulfur emissions, Global Environ. Change, 16, 207-220, doi:10.1016/j.gloenvcha.2006.01.001, 2006.

Streets, D. G., Bond, T. C., Carmichael, G. R., Fernandes, S. D., Fu, Q., He, D., Klimont, Z., Nelson, S. M., Tsai, N. Y., Wang, M. Q., Woo, J. H., and Yarber, K. F.: An inventory of gaseous and primary aerosol emissions in Asia in the year 2000, J. Geophys. Res., 108, 8809, doi:10.1029/2002jd003093, 2003.

Streets, D. G., Wu, Y., and Chin, M.: Two-decadal aerosol trends as a likely explanation of the global dimming/brightening transition, Geophys. Res. Lett., 33, L15806, doi:10.1029/2006GL026471, 2006.

US Environmental Protection Agency (EPA): Regional interim emission inventories (1987-1991): Vol. 1. Development method- 
ologies, Washington, DC, 1993.

US Environmental Protection Agency (EPA): National air pollutant emission trends, procedures document, 1990-1996, EPA-454/R98-008, 1998.

US Environmental Protection Agency (EPA): National air pollutant emission trends, 1900-1998, EPA-454/R-00-002, 2000.
Wang, S. W., Zhang, Q., Streets, D. G., He, K. B., Martin, R. V., Lamsal, L. N., Chen, D., Lei, Y., and Lu, Z.: Growth in $\mathrm{NO}_{\mathrm{X}}$ emissions from power plants in China: bottom-up estimates and satellite observations, Atmos. Chem. Phys., 12, 4429-4447, doi:10.5194/acp-12-4429-2012, 2012.

Wild, M.: Global dimming and brightening: A review, J. Geophys. Res., 114, D00D16, doi:10.1029/2008JD011470, 2009. 